\title{
Translating Obligations: Tamassuk and Färigh-khaț̣i in the Indo-Persian World
}

\author{
Nandini Chatterjee \\ University of Exeter, Exeter, UK \\ n.chatterjee@exeter.ac.uk
}

\begin{abstract}
A necessarily widespread feature of language practice in the Persianate world was the need for translation of speech and text, with a range of lexical and semantic challenges involved in taking meaning from one language to another. This article focusses on legal translation, with its highly functional aims, by following the career of a pair of Indo-Persian legal forms known as tamassuk and färigh-khatți, used for recording obligation and requital respectively. Tracing their reincarnations from Persian into Marathi, Hindi and Bengali, this article reveals several forms of boundary-crossing: doctrinal, jurisdictional, political and linguistic. In doing so, it explores the legal mindscapes in the early modern Indo-Persian world, spilling from the late Mughal into the colonial, and shows how multilingualism functioned within specific parts of the Persianate cosmopolis.
\end{abstract}

\section{Keywords}

debt - obligation - Islamic law - Persianate world - Mughal Empire - colonialism legal translation

\section{Introduction ${ }^{1}$}

Writing in the early eighteenth century in his native city of Delhi, the enfant terrible of the eighteenth-century Indo-Persian literary world, Mir Muhammad

1 The Romanisation of Arabic and Persian words in this article follows JESHo's modified IJMES guidance, and a LOc-based common schema adopted for this special issue, for Bengali, 
Ja'far 'Zatalli' of Delhi (d. 1713), ${ }^{2}$ penned a munshāt, an epistolary and formulary that offered models for writing letters, legal documents and other kinds of ornate, specialist prose. ${ }^{3}$ Zatalli's munshāt included a model for a kind of legal document called 'tamassuk,' which was used to record obligations, including cash debts. Since Zatalli's munshāt was a spoof, however, the legal document was aimed less at creating a record than provoking laughter.

I, who am Shaykh Maula, possess neither grinding-stone nor hearth, [and] am resident in the town of Deserted-city, district Hidden-city, since I have forcibly taken an infinite amount [of money] from Lala Tahmat Ram, the half of which is not even one big cowrie, and taken [the money] into my possession, I declare that I will not return [this money] until qayāmat (the Day of Judgement). These words are written and given in the manner of talam talla ${ }^{4}{ }^{4}$ so that in the future they do not act as record and are of no use at the time of need. Written on Saturday, wrong regnal year. ${ }^{5}$

However silly and slapstick Zatalli's humour may be, its meaningfulness and ability to entertain depended primarily on the recognisability of the form of the legal document, and then on the inversion of the expected specific contents. Thus, while the fictive homeless shaykh offered no security for the infinite loan he had taken by force, which he promised never to return, the document thus formulated was still readily recognisable, if not acceptable, as a tamassuk-a kind of legal document in evident use for recording obligations from Jerusalem to Chittagong.

Gujarati, Hindi, Marathi and Rajasthani words. To reconcile the two schemas, we have introduced minor variations to the LOC schema to ensure distinct diacritics. In many cases, the same word occurs in multiple languages but is pronounced differently; Romanisation used follows the phonetic context. For the common schema, see pp. 483-5 of this issue.

2 S.R. Faruqi, "Burning Rage, Icy Storm: The Poetry of Ja'far Zatalli" (unpublished lecture, University of Texas-Austin, 2008) http://www.columbia.edu/itc/mealac/pritchett/oofwp/srf/ srf_zatalli_20o8.pdf; also see S. Wigh, "Power, Patronage and Sexuality In Mughal India: A Study Of The Language of Biharilal \& Mir Jafar Zatalli," unpublished thesis (Jawaharlal Nehru University, 2014).

3 On medieval European epistolaries and formularies, see C. Poster and L. Mitchell, ed., Letter Writing Manuals and Instruction: From Antiquity to the Present: Historical and Bibliographic Studies (Columbia: University of South Carolina, 2007); on munshāts, see R. Islam, A Calendar of Documents on Indo-Persian Relations, 1500-1750 (Tehran: Iranian Cultural Foundation, 1979): I; and further ahead in this article.

4 A nonsense phrase, which is a phonetic play on the Hindi/Urdu verb tā $\bar{l} n \bar{a}$, to postpone.

5 Zatal-Nāma (Kulliyat-iJaffar Zatalli) (New Delhi: Anjuman-i Taraqqi-yi Urdu, 2001): 112. 
The special collection in which this article is placed seeks to explore the contours and implications of the 'Persianate world' along the specific axis of economic transactions and their record. ${ }^{6}$ Within that agenda, this article explores the legal documentary form called tamassuk-which Zatalli spoofed - together with its twin, the färigh-khatți or document of release from obligations. By tracking the circulation and use of these documents in the late Mughal Empire and, later, the Maratha and British empires, the article will propose a back-story to Zatalli's and his audience's familiarity with these forms, reaching back into Arabic-language Islamic legal documentation procedures on the one hand and Indo-Persian legal and administrative recording styles on the other. Several languages apart from Arabic and Persian will make their appearances in this story; Zatalli himself wrote his pseudo-tamassuk in an early form of Rekhta/Urdu; ${ }^{7}$ but others, as we shall see, wrote genuine tamassuks and their twins, the fārigh-khațịis, in other forms of old Hindi (Malwi/ Rangri), Marathi and Bengali. Uniting all these instances is the idea of obligation and fulfilment, recorded as a bond and a release, but with changes in formulae and vocabulary that attest not just to the existence and transcendence of jurisdictional boundaries, but to semantic and phonetic ones as well.

The key idea, here, then is that of legal translation, which, as legal scholars have repeatedly shown, is much more complex than replacing one set of words with their equivalents. Such equivalents do not necessarily exist, because

6 N. Green, ed., The Persianate World: The Frontiers of an Eurasian Lingua Franca (Oakland: University of California Press, 2019); also see the introduction to this volume.

7 The history of Urdu (and its nominal alter-ego, Hindi) is politically fraught. Subsequent to the cultural-linguistic nationalisms of the nineteenth century, Urdu and Hindi have emerged as languages that are believed to be distinct by their speakers and their promulgating institutions. The distinction is most clearly expressed graphically-Urdu uses a right-to-left cursive script derived from Arabic, and Hindi uses a left-to-right Indic script, Devanagri. The languages continue to share a nearly identical grammatical structure, and a huge portion of their vocabulary, although this can vary very widely depending on the register of use. The classic work on the movements leading to this official and politicised distinction is C. King, One Language, Two Scripts: The Hindi Movement in Nineteenth-Century North India (New Delhi: Oxford University Press, 1994). A differently oriented story of Urdu's modernity is told by K. Datla, The Language of Secular Islam: Urdu Nationalism and Colonial India (Hyderabad: Orient Blackswan, 2013). A longer-term and more language-focussed work is W. Hakala, Negotiating Languages: Urdu, Hindi and the Definition of Modern South Asia (New York: Columbia University Press, 2016). The pre-modern histories of the range of linguistic styles-Khari Boli, Awadhi, Magadhi, Gujri, Dakhani and Braj Bhasha—that were later compacted into Urdu and Hindi are examined in F. Orsini, ed., Before the Divide: Hindi and Urdu Literary Culture (Hyderabad: Orient Blackswan, 2010). In the twentieth century, the Linguistic Survey of India still noted that the divides between these languages were more like 'waves' than lines. 
languages develop in specific historical, cultural, and (in the case of law) institutional contexts, producing lexicons that are not fully fungible. There are multiple and ubiquitous pitfalls to the translation of the shortest legal text, be that a deed, a testimony, a judgment or a statute, which include the use of inadequately precise, excessively specific or legally (if not linguistically) wrong equivalents. Legal translators may adopt a number of strategies, which include using paraphrases, replicating words from the original language or producing neologisms. In all such cases, the challenge is to produce the intended result, although what result is preferred may depend on the operating overarching principles-fidelity to the original system that produced a text, or to the target system, or a good greater than or distinct from either system. ${ }^{8}$

While these specific concerns pertain to law, the difficulty of translation is shared across multiple disciplines, including literature. Languages are simply not transparent and identical media; lexical disjuncture is the inevitable product of cultural encounters, and when they lead to moral or aesthetic judgements, they often reveal real power asymmetry. ${ }^{9}$ However, even the most sensitive of translators is bound to make significant choices-to produce results s/he perceives as desirable. Those decisions must involve manipulation of the 'chain of signification' or the culturally loaded implicit and explicit intertextual references that make any text intelligible; some scholars insist that this manipulation is bound to be violent. ${ }^{10}$

Stepping back into history and into the Indo-Persianate world, research has shown how translators from Sanskrit to Persian in seventeenth-century India consciously dealt with the dilemmas strikingly similar to those faced by professional legal translators even today-by choosing idiomatic translation and cultural interpretation over lexical fidelity. ${ }^{11}$ By studying one of the great-

8 L. Wolff, "Legal Translation." In The Oxford Handbook of Translation Studies, ed. K. Malmkjaer and K. Windle (Oxford: Oxford University Press, 2011): 228-42; J. Xuan and D. Xiaobo, "Equivalence Theory and Legal Translation: Achieving Functional Equivalence in Chinese and English Legal Terminology." Chinese Semiotic Studies 13/2 (2017): 123-35; S. Sarcevic, New Approach to Legal Translation (The Hague: Kluwer Law International, 1997).

9 One such encounter, especially over the translation and usage of the Chinese character for 'yi' in treaties signed after the Anglo-Chinese Opium Wars, was interpreted as a 'clash of empires' by L. Liu in her Clash of Empires: The Invention of China in Modern World Making (Cambridge, Mass.: Harvard University Press, 2004).

10 L. Venuti, ed., The Translation Studies Reader (London: Routledge, 200o); L. Venuti, The Translator's Invisibility: A History of Translation, 2nd ed. (Abingdon: Routledge, 2008).

11 A. Martin, “Translator's Invisibility': Strategies of Adaptation in Persian Versions of Indian Tales from the Mughal Period." Iran Namag 2/2 (Summer 2017): xxiv-xxxvii; also see the instances from a more broad ranging period discussed in C. Ernst, "Muslim 
est state-sponsored projects of translation - that of the Mughals to translate Sanskrit texts to Persian-scholars such as Audrey Truschke have also alerted us to the multi-layered processes of translation. The picture of variably skilled multi-person translation teams, with the interposing of orality between the processes of scribing, appears very similar to research processes out of which this collection of papers has arisen! ${ }^{12}$

Studies in Indo-Persianate translation history have, thus far, focussed on literary or learned texts - such as of medicine, linguistics, theology and law. These texts of high aesthetic or intellectual status are associated with a single author, whether real or attributed. In contrast, the materials that this article focusses on - legal documents of debt and requital — are such that their precise authorship is irrelevant; authorial innovation was not just unnecessary but undesirable. Here, it is the form itself that is the hero; and here we may observe how that form was stabilized, but also transmitted and transformed across linguistic and institutional contexts. These patterns reveal to us what worked as a legal document; what looked and even sounded like a legal document in seventeenth- to nineteenth-century India. In many, if not all cases, we also have the opportunity to follow such documents within their archives, to discover how such documents were institutionally deployed and socially received: how they really worked in their own historical contexts. Thus we have the opportunity of taking further the findings derived, until now, principally from the fields of literary production and transmission.

In binding and releasing through contracts, people have left records that we can interpret to build our understanding of how the 'Persianate' operated. It was not merely a socio-geographical domain marked by the use of Persian as an umbrella prestige language and its associated literary, aesthetic and ethical values; nor even a congeries of regionally specific pairings between Persian and regional vernaculars. The Persianate was both these things, but it was also necessarily a domain of translations, slippages, barriers and boundary crossings. And while it encompassed people and artefacts who or which were not confessionally Muslim, Islam was a key source of ideas, lexicon and laws. The Persianate was also Islamicate; we have always known this, but it is important to remind ourselves once again. ${ }^{13}$

Studies of Hinduism? A Reconsideration of Arabic and Persian Translations from Indian Languages." Iranian Studies 36/2 (2003): 173-95.

12 A. Truschke, Culture of Encounters: Sanskrit at the Mughal Court (New York: Columbia University Press, 2016).

13 Here, I differ from the emphasis placed on the 'supra-religious' nature of the Persianate by, for example, R. Eaton, India in the Persianate Age, 1000-1765 (London: Allen Lane, 2019): 13-16. Islam was not negated nor rendered insignificant by the vast numbers of 
In exploring such Persianate and Islamicate exchanges through the history of a legal form, the focus in this paper is not on jurisprudence, but on traceable practices of documentation, and on the rule-books that guided such routine work. Looking for doctrinal discussions about the incurring and repayment of debts did not seem to me productive in this case. The methodology of connecting documentary practices to doctrine has a formidable genealogy, but it assumes certain things, such as the presence and predominance of Islamic legal institutions, and the channeling of transactions via scribes with Islamic legal training, ${ }^{14}$ none of which holds true for the Mughal Empire, ${ }^{15}$ and even less for the Maratha and British empires. The translation and vernacularisation of Islamic law in South Asia must have taken place less in the domain of academic jurisprudence, and more in the arena of practice.

\section{1 \\ Binding and Releasing across the Islamic World}

Debt and its recording are widely shared as human experiences, but the cultural context determines the form such recording would take. The tamassuk and fārigh-khațīi were Islamic legal documents for recording such dealings, but with variable geographical prevalence. As such, they permit us a focused and non-juristic insight into the processes of localisation, or vernacularisation of Islam, and Islamic law in particular. ${ }^{16}$

non-Muslim partakers of Persianate culture, nor by the encompassing of non-Muslim religious and non-religious texts and ideas.

14 W. Hallaq, "Model Shurūt Works and the Dialectic of Doctrine and Practice." Islamic Law and Society 22/2 (1999): 109-34.

15 M. Alam and S. Subrahmanyam, "The Making of a Mūnshī." Comparative Studies of South Asia, Africa and the Middle East 24/2 (2004): 61-72; K. Chatterjee, "Scribal Elites in Sultanate and Mughal Bengal." Indian Economic and Social History Review 47/4 (2010): 44572; R. Kinra, "Master and Mūnshī: A Brahman Secretary's Guide to Mughal Governance." Indian Economic and Social History Review 47/4 (2010): 527-61; R. O'Hanlon, "The Social Worth of Scribes: Brahmins, Kāyasthas and the Social Order in Early Modern India." Indian Economic and Social History Review 47/4 (2010): 563-95; H. Bellenoit, "Between Qānūngōs and Clerks: The Cultural and Service Worlds of Hindustan's Pensmen, c. 1750-185o." Modern Asian Studies 48/4 (2014): 1-39; R. Kinra, Writing Self, Writing Empire: Chandar Bhan Brahman and the World of the Indo-Persian State Secretary (Oakland: University of California Press, 2015).

16 Once again, scholarship on the vernacularisation of Islam tends to focus on literary production. For an excellent example, see R. Ricci, Islam Translated: Literature, Conversion and the Arabic Cosmopolis of South and Southeast Asia (Chicago and London: University of Chicago Press, 2011). 
The Quran (2:282-3) instructs the faithful to carefully record debts, in writing, by the hand of an honest scribe and in the presence of two male (or one male, two female) witnesses. The only exception is for immediately completed transactions, or those undertaken during a journey. A pioneering study based on the Comparing Arabic Legal Documents database ${ }^{17}$ has shown that in the first five centuries of Islam, a twinned set of documentary forms, known as the zikr haqq and baräa, performed the binding and releasing functions recommended by these Quranic injunctions. Daaif speculates that these forms were relatively short lived, and replaced by the more generic iqrār. ${ }^{18}$ Indeed, dozens of iqrārs recording debts and payments dated from the twelfth century CE onwards have been preserved in archives from across the medieval Islamic world. ${ }^{19}$

In this paper, I suggest that the story may not have ended here. Another chapter in the recording and voiding of obligations in the Islamicate world opened with the emergence of an early modern documentary pair-the tamassuk and the fārigh-khaț̣ī. It would take a project of different proportions to establish the full history of the documentary pair and the extent to which it was a specifically Persianate and even Indo-Persian story, but following is what I have been able to establish.

The word tamassuk itself is Arabic in origin; it derives from the root $m-s-k$ which means to grab, clasp or seize. As such, it is part of one of those beautiful word-constellations of ever-widening figurative meanings, that Arabic is distinctive for. Modern Standard Arabic dictionaries suggest that tamassuk could be a 'written commitment, IOU.'20 Documents referred to as tamassuks have been discovered from the Ottoman territories of North Africa, but their specific functions are unclear. Certain entries in seventeenth-century registers from a shari'a court in Tripoli record disputants producing tamassuks during

17 See http://cald.irht.cnrs.fr/php/ilm.php.

18 Lahcen Daaï, "La Barāa: Réflexions sur la Fonction et L'évolution de la Structure de la Quittance." Annales Islamologiques 48/2 (2014): 3-6o.

19 G. Khan, Arabic Legal and Administrative Documents in the Cambridge Genizah Collections (Cambridge: Cambridge University Press, 1993). In the Genizah documents, debts appeared to have been recorded through straightforward iqrārs, e.g. No. 37. Also, there were the Arabic and Arabic-Gujarati deeds often simply designated waraqa-paperoperating across the Indian Ocean in the nineteenth and twentieth centuries. Waraqas recording debt inevitably included iqrārs that acknowledged that monetary obligation, the parties and the terms. F.A. Bishara, A Sea of Debt:Law and Economic Life in the Western Indian Ocean, 1780-1950 (Cambridge: Cambridge University Press, 2017); for an example of an Indian Ocean debt waraqa recording an iqrār, see p. 72.

20 For example, J.M. Cowan, ed., The Hans Wehr Dictionary of Modern Written Arabic (Wiesbaden: Otto Harassowitz, 1979): 9o8-9. 
court cases as evidence of monies owed to them. ${ }^{21}$ In seventeenth-century court records from other parts of the Ottoman Empire, tamassuks appear to have been title-deeds to property more generally. ${ }^{22}$ Without access to the actual document or its full text, it is hard to tell whether these latter Ottoman tamassuks have anything to do with debts, however. Colin Mitchell has also seen manuscripts of a sixteenth-century formulary from Safavid Iran, titled Inshä'-yi $\bar{A} l a m$ a $r \bar{a}$, whose section of legal documents includes tamassukāt. ${ }^{23}$ Thus, documents called tamassuk are in evidence in property-related matters in early modern Islamic empires from South Asia to Anatolia, but their specific usage as records of debt may or may not be South Asia-specific: it is beyond the scope of this article to establish this.

Just as the barāa complemented the zikr haqq, there was a document of 'release' to complement the tamassuk; this Indo-Persian documentary form was called the fārigh-khațtī. The Arabic-origin word färigh means empty, or free; Indo-Persian documents bearing that name often referred back to a tamassuk and noted that the obligations stated therein had been wholly or partially fulfilled. In some other cases, fārigh-khațtīs could refer back to obligations that were inherited or implied rather than contracted. Unlike the tamassuk, the name of this documentary type appears to be wholly South Asian. Also compared to the tamassuk, the fãrigh-khațị developed a large number of nonPersian (but Persianate) avatars - in Hindi, Bengali, Gujarati, Rajasthani and Marathi among others. Following this documentary pair in action across the Mughal, Maratha and even British empires allows us to study legal translation in some core sub-regions of the Persianate world. ${ }^{24}$

As a documentary form, fārigh-khațtīis spanned the fiscal-administrative and commercial worlds of the Mughal Empire. In a much-cited seventeenthcentury autobiography of a Jain merchant from north India, Banarsidas, we have at least two instances of use of the word phärkatī (फारकती-a corruption of

21 C. Mallat, "From Islamic to Middle Eastern Law, Part II." The American Journal of Comparative Law 52/1 (2004): 224. There are apparently 70 such registers from the court of Tripoli, ranging in date from 1684-1723; Mallat's article is based on the published edition of one such register from the seventeenth century.

22 S. Ayoub, “The Sulțān Says': State Authority in the Late Hanafĩ Tradition." Islamic Law and Society 23/3 (2016): 239-78, esp. p. 264.

23 C. Mitchell, "Persian Rhetoric in the Safavid Context: A Nurbakhshiyya Treatise." In Literacy in the Persianate World: Writing and the Social Order, ed. Brian Spooner and William L. Hanaway (Philadelphia: University of Pennsylvania Museum of Archaeology and Anthropology, 2012): 207.

24 In referring to the Indian subcontinent as a core region of the Persianate world, I am referring to pre-nineteenth-century political and cultural realities as well as recent scholarship, such as Green, The Persianate World. 
fārigh-khaț̣ī), once referring to fiscal dues and the other time, to commercial relations.

In the first instance, Banarsidas described his father's service in Bengal in the 1570s, when the Mughals where still struggling to wrest the region from the Afghans. Banarsidas's father Kharagsen served as pōtdār ( fōtedār, tax-collector and treasurer) under the short-lived Afghan ruler Sulaiman Khan Karrani (r. 1565-72), who moved the capital from Gaur to Tanda. ${ }^{25}$ Assisted by two underlings called kārkuns, Kharagsen's job was to collect taxes from four districts. As a pious Jain, he focussed mostly on his religious observances, and was lax with documentation, although the conventions were clear:

\section{Karei bisās na lekhā lē̄/sabkaun phārkatī likhī dē̄}

(He trusted and did not take anything in writing/He wrote out phārkatīs to everyone).

Here, phārkatīs were meant to act as receipts, recording the due transfer of tax revenues from one government official to another.

The next reference Banarsidas makes is to a more commercial relationship. Describing a prolonged and disputed dissociation from a former business partner based in Agra, then capital of the Mughal Empire, Banarsidas noted the frustrating process of examining and settling of accounts and producing the essential document- the phārkatī-for dissolving the partnership. Banarsidas had to beg intermediaries to impress upon the more powerful business partner:

\section{Agili phārkatī likhau/pichilō kāgad phārīi.}

(First [get him to] write a phārkatī, then tear up the [older] documents.)

Eventually, the partner relented:

Lekhā kāgad liye mangāi/sājhā pātā diyā chukā̄ Phārkatì likhì dìnì dōi

\footnotetext{
25 R. Eaton, The Rise of Islam and the Bengal Frontier, 1204-1760 (Berkeley: University of California Press, 1993): 140.
} 
[He] called up the records, settled all accounts, [and] wrote out the phārkatī. ${ }^{26}$

Banarsidas's desperation demonstrated that the phārkatī was an essential document to have for the secure termination of commercial relations. Thus as in the Arabic-writing early Islamic world, the phārkatī (fārigh-khațtịi) worked to void financial obligations, ranging from the fiscal to the inter-personal. But where did the Indian terms come from?

They did not come from Islamic jurisprudential texts or books of $f i g h$, certainly not the Hanafi fiqh books that were most well-regarded in Mughal India. The concept of recording and receipting the fulfilment of obligations existed in Islamic law books. In the imperially-sponsored seventeenth-century Fatāwa-yi 'Álamgì $\bar{\imath}$ (henceforth FA), which followed half a century after Banarsidas's autobiography, the Ardhakathānaka, doctrinal discussion on the fine points of debt and repayment was followed by instructions on how to write a sulh-nāma (a resolution deed). The FA indicated that this document would record a duly structured iqrār, a legal declaration, that the monies due had been received. In terms of the clauses and formula it prescribed, the sulh-nāma it described was essentially a fārigh-khațtịi. ${ }^{27}$

The terms tamassuk and fārigh-khațtī, which, as Banarsidas's text shows us, had already been vernacularized in northern and eastern India in the sixteenth century, occur instead in the workaday manuals of Persian-writing scribes. These were the munshis, who doubled up as secretaries, tax officials and account-keepers, and who guided ordinary users of law in choosing the appropriate documentary forms for recording their dealings, and then penned their claims and obligations. The archetypical Mughal munshi was the Hindu kāyastha or khatrī, trained in Persian language chancellery procedure and steeped in Persianate literary mores, but not a jurist by training nor, indeed, a Muslim by confession. One of the most prolific genres of writing by Mughal

26 Verses 51 and 566 in Half a Tale: A Study in the Interrelationship between Autobiography and History [Ardhakathānaka of Banarsidas], trans. and ed. M. Lath (Jaipur: Prakrit Bharati Sansthan, 1981): 99, 249 .

27 S.N. Burhanpuri et al., Fatāwa-yi Ālamgīrī, trans. M.S.A. Ali, vol. 10 (Lahore: Maktaba Rahmaniyah, n.d.): 228-38. 
munshīs was a kind of manual intended to train new entrants to the profession and to provide them with usable models for legal drafting: formularies.

Such formularies were called inshä' or munshāt. Derived from an Arabic root implying creation, including creative writing, inshā' was a Persian prose genre that appeared around the eleventh century. ${ }^{28}$ The earliest Indian inshā'/ munshāt was probably the Aijjäz-i Khusravī, produced by the Khilji court poet Amir Khusrau in the fourteenth century. Until the seventeenth century, munshāts produced in India were mainly collections of diplomatic letters, royal orders and aristocratic correspondence. ${ }^{29}$

From the seventeenth century, Indian inshā' or munshāt collections began to include a section on legal documents or qabälajāt. ${ }^{30}$ These were akin to the shurūt sections of Islamic law books, but did not entirely mirror them, because munshāts also included royal and non-royal epistles, as well as highly specialized documentary forms related to locally specific charitable and fiscal practices, such as the farmān-i madad-i ma'ash which replaced waqf-nämas in Mughal India.

Tamassuks and fārigh-khațtīs abound in munshāts. The seventeenth-century Inshä'-i Harkaran, reputed to be the first inshā' produced by a Hindu in India, included two tamassuks, one for debt, and the other for a lease; and a khatt-i färighki-yi ma'amala. ${ }^{31}$ Using a methodology of structural and formal analysis demonstrated by Christoph Werner in his work on Qajar Iranian documents, ${ }^{32}$ we may thus compare the model fârigh-khaț̣i document recommended in Harkaran's munshāt, and several of the Mughal-era fārigh-khațịis that I will discuss in the following section.

28 J. Paul, "Inshä' Collections as a Source of Iranian History." In Proceedings of the Second European Conference of Iranian Studies (Bamberg, 1997), ed. B. Fragner et al. (Rome: IsMEO, 1995): 535-4O; C. Mitchell, "Safavid Imperial Tarassul and the Persian Inshä' Tradition." Studia Iranica 26/2 (1997): 173-209.

29 E.J. Flatt, "Practicing Friendship: Epistolary Constructions of Social Intimacy in the Bahmani Sultanate." Studies in History 33/1 (2017): 61-81; Manāzir al-Inshä, ed. M. Madankan (Tehran: Fahrangistan, 1381/2002).

30 N. Chatterjee, "Mahzar-namas in the Mughal and British Empires: The Uses of an Indo-Islamic Legal Form." Comparative Studies in Society and History 58/2 (2016): 379-406.

31 The Forms of Herkern, ed. Francis Balfour (Calcutta, 1781): 172-3, which offers both the Persian and English texts. Although it has long been recognised as a seventeenth century text by historians of Mughal India, and indeed the author notes as such in the introduction, several manuscripts examined by the Lawforms team found documents very much from the late eighteenth century included towards the end of the text. This may be a case of later editorial 'expansion'; it requires further study.

32 C. Werner, "Formal Aspects of Qajar Deeds of Sale." In Persian Documents: Social History of Iran and Turan in the Fifteenth-Nineteenth Centuries, ed. N. Kondo (London: Routledge Curzon, 2003): 13-49. 
Debt-release documents in a Mughal (17th-century) munshāt

Statement of purpose

Identification of parties, with the deposing party in first person $(\mathrm{I}, \ldots)$

Clause asserting free will

Substance of the transaction

Confirmation of money transferred

Exclusion of future claims

Type of document

Closing formula

Date

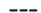

Debt-release documents in Mughal-era (17th- and 18th-century) archives Invocation

Statement of purpose

Identification of parties, with the deposing party in first person $(\mathrm{I}, \ldots)$

Usually present ( $\mathrm{n} / \mathrm{a}$ in current documents)

Substance of the transaction

Amount of money

Confirmation of money transferred

Exclusion of future claims

Type of document

Closing formula

Date

Seal of authority

Witnesses

FIGURE 1 Comparison of formal aspects of debt-release documents in Mughal formularies and Mughal archives

Barring the elements that would appear in actual legal documents (seals, witness clauses etc.), there is thus a close structural and lexical correspondence between the legal forms proposed in the Mughal formularies and actual Mughal-era documents, so that not only do the identifiable elements appear in the same sequence, but the words used to encode those elements (such as the closing formula) is frequently in the form of a stable conventional phrase-in chand kalma ba-țariq-i fārigh-khaț̣i navishta dāda shud ka sā̄n̄ al-ḥāl sanad/ hujjat bāshad (these words in the manner of a fārigh-khațți are written and given, so that they may be a record for the future). This formula, with minor variations, appears in both the model and the actual documents.

Also, compared to the many Iranian transactional deeds available from the eighteenth and nineteenth centuries, the Mughal and post-Mughal IndoPersian deeds (fārigh-khațtis and others) tend to radically abbreviate the invocation and praise of God, limiting it to short phrases such as 'Allahü Akbar'; 'Bismillah' or even just an 'Alif'. Pious quotations from the Quran are minimal or absent, as are ornate laudatory praises of God and his Prophet, any reference to the majlis or the location of the act of transacting, in the presence of a qazi or otherwise, even when such authority figures were clearly present. On the other hand, the Indian documents always state their own type (the 
documentary genre to which they belong), which the Iranian documents do not. Also, Mughal documents strive to reproduce the orality of the declarations made, such that the documents frequently begin with and retain the first person throughout, opening with 'Bä'is tahrīr-i in sutür ānka, manka (The reason for writing this document is that, I, who am ...)' or opening in the third person and slipping quickly into the first with 'The reason for writing this document is that, X made a claim, and said that, I, ...'

Mughal documents were therefore highly regular and conformed to the models offered in the Mughal munshāts and somewhat indirectly, but still recognizably, with the models in leading Hanafi books of fiqh. It is fully possible that such regularity in Mughal documents was produced by phonetic memorization and word-specific comprehension without full working knowledge of Persian, and was reproduced through professional practice rather than direct copying from manuals. This has been plausibly argued with reference to contemporary non-Persian documents for which there are no known formularies. ${ }^{33}$ A performance-centred view of texts similarly pushes us to think of munshāts as written repositories of working knowledge that enabled legal documentation, even if a great deal of that knowledge was actually kanțastha (literally: situated at the throat; memorized $)^{34}$ of the working scribe.

In this connection, it is worth underlining a point noted above, namely that Persian legal and administrative documents produced in India in the extended Mughal period (that is, between the sixteenth and nineteenth centuries) tended to state their own type, usually in the first or final lines of the document. This was true of nearly all grades and classes of documents, ranging from the imperial farmān down to the humble bai'-nāma. The tendency, therefore, was for the proliferation of highly specific types of legal and administrative documents, functionally tied to specific types of orders/transactions. Such specificity may have permitted a doctrinally superficial or obtuse, manualbased approach to legal documentation. This would have obviated the need for regular recourse to advanced jurists, and permitted the vast majority of villagers and townsfolk in the Mughal Empire, the majority of whom were Hindus, to get by with the services of principally by non-Muslim Persian-writing scribes.

33 S. Guha, "Mārgī, Deśi and Yāvanī: High Language and Ethnic Speech in Maharashtra." In Mārga Ways of Liberation, Empowerment, and Social Change in Maharashtra, ed. M. Naito, I. Shima, and H. Kotani (New Delhi: Manohar, 2008): 133-46; a similar point about variable combined literacies is made in P. Dhavan, "Persian Scholarly Networks in Mughal Punjab." In The Persianate World, ed. N. Green: 166-9.

34 F. Orsini and K.B. Schofield, ed., Tellings and Texts: Music, Literature and Performance in North India (Cambridge: Open Book Publishers, 2015): 1-30. 
Thus we have clear correspondence between popular Mughal books of model legal documents (munshāts) and the actual legal documents in existence. But it is important to establish who used tamassuks and fārigh-khaț̣īs, and in what contexts. That is to say, what were the social lives of these documents? To answer this question, it is necessary to take a short detour into the nature and distribution of Mughal-era documents.

Historians have long lamented the disappearance of the Mughal archive. In my recent book, I have argued that this vacuum is the product of looking in the wrong place. ${ }^{35}$ By this I mean two things. The first is that the notion of such an absence is factually untrue; even if we restrict our understanding of the archive to centralized repositories of documents intended to create a store of retrievable records created by state agencies. There are two immense collections of Mughal-era documents available to researchers, both pertaining to the late-acquired Mughal province of Golconda. Only one of these has been used to any significant extent. ${ }^{36}$ The first collection is held at the Telangana State Archives in Hyderabad, and the other at the National Archives of India, New Delhi. Together, they comprise around 250,0oo documents $(+/-25 \%)$.

But my second and principal point, and the one most germane to this paper, is this: in the light of work from at least other Islamicate and early modern South Asian imperial contexts, we need to re-examine our understanding of archives and archiving processes. We have to divest ourselves of the modern colonial imaginary of state-owned record series documenting the activities of state departments, geared towards the reliable retrieval of records, stored in special purpose-built/-procured buildings. The great majority of Mughal-era documents remained as collections built up in the households of landed families and institutions. These documents were necessarily diverse, in the sense that they consisted of materials considered significant for the family's identity and entitlements—and so could and did comprise family chronicles,

35 N. Chatterjee, Negotiating Mughal Law: A Family of Landlords Across Three Indian Empires (Cambridge: Cambridge University Press, 2020). A very similar argument is made with regards to Fatimid records for Egypt and Syria by Marina Rustow, The Lost Archive: Traces of a Caliphate in a Cairo Synagogue (Princeton: Princeton University Press, 2020): 1-19 and passim.

36 J.F. Richards, The Mughal Administration of Golconda (Oxford: Clarendon Press, 1975); M.Z.A. Shakeb, Mughal Archives (Hyderabad: State Archives, 1977), and subsequent volumes in the same series. For a recent article, see S. Dayal, "Making the 'Mughal' Soldier: Ethnicity, Identification, and Documentary Culture in Southern India, c. 160o-170o." Journal of the Economic and Social History of the Orient 62/5-6 (2019): 856-924. 
talismans and letters, as much as land deeds. Such documents, now gathered and deposited in various state and private archives and libraries, have been used extensively, but treated as records of 'state' processes, with little regard for the lineage and locality contexts in which they were produced. And all the while, the lament for the 'lost' central Mughal archive continues. The fact that some of the most important state records in the highly bureaucratic Maratha Empire were housed in Nana Phadnavis' household ${ }^{37}$ should push us to rethink the private-public distinction in record-keeping in Persianate South Asia, and look further into the role of lineages as record-keepers. I propose that quite like most other early modern Islamic regimes apart from the Ottomans, ${ }^{38}$ the Mughal Empire acquired vast amounts of written information, with prodigious procedures for issuing and copying of documents, but did not necessarily store them indefinitely in a central repository or in branches thereof. Instead, 'households' of eminent nobles down to the village landlords maintained durable record stores, aimed at recording not state processes, but the rights of their own lineages.

This hypothesis about the terrain of documentation in Mughal and postMughal India will be tested in another publication. But it informs my approach as I present in this section one such household's collection of records, which I have named the 'Purshottam Das collection.' The eponymous Purshottam Das was a seventeenth-century landlord or zamindār who also held the hereditary post of local record keeper or qānungō, in the district of Dhar, in the southwestern corner of the Mughal province of Malwa (see map for the issue). Established from the sixteenth century, perhaps earlier, the family held several villages' worth of land, tax-free, and a host of other claims to the revenue proceeds in other villages. After the weakening of the Mughal Empire, Dhar became part of the federated Maratha Empire, specifically the kingdom of a Maratha family known as the Puwars. In the early nineteenth century, Dhar entered into a treaty with the English East India Company and became an indirectly ruled 'princely state.' Eventually, after Indian independence, Dhar became part of the Indian province called Madhya Pradesh.

Through a complex and protracted process, I was able to recover 188 documents and several other materials from the 'Purshottam Das' family's now-dispersed collection, from three different locations-two in India and

37 G.S. Sardesai, Handbook to the Records in the Alienation Office, Poona (Bombay: Government Central Press, 1933): 36 .

$38 \quad$ P. Sartori and J. Pickett, "From Archetypical Archive to Cultures of Documentation." Journal of the Economic and Social History of the Orient 62/5-6 (2019): 773-98, at p. 783 . 
one in Kuwait. The documents are predominantly in Persian, with around 18\% bearing some writing in Rajasthani and/or Hindi (Rangri), written in an archaic Nagri script, or in Marathi in the Modi script. 'True' bilingualism, as in the main text in two languages and scripts is less frequent. Nearly all documents relate to some kind of entitlement, whether to exemption from taxes, or to an office, or to the responsibilities and perks of office-holding. The documents are a mix of originals, that is, with seals and signatures contemporary to the legal event described, and self-described copies, with naql written above the main body of text, often, but not always authenticated by the seal of the local qazi. The date range is from 1584 to the 1920 ; with the densest cluster in the seventeenth century. The forms of documents are various; they include various levels of orders (farmāns, nishāns, parwānas, dastaks); petitions (iltimās; 'arżdāsht); tax contracts and related documents (qaul qarārs; āwarjas, chak-nāmas); documents related to adjudication or validation (mahżar-nämas; tasdiqs and sanads of judicial decisions); and most importantly for us, those recording inter-personal transactions (hiba-nāmas [gift], girwì-nāmas [pawn], fārigh-khaț̣̣̂̂s, and lā-da'wā sulh-nāmas). Together, these documents cover a range of functions from the royal/imperative to the transactional; they derive forms from both the Arabic-Islamicate and the specifically Persianate, including from Indo-Persian traditions of documentation.

\section{Debt and Repayment in a Mughal Landlord's Family}

So, to summarise, five out of 188 documents from this reconstructed household archive are fārigh-khațtīs and refer to themselves as such. Four of these are in Persian and one in Rangri (western Hindi, close to Rajasthani). ${ }^{39}$ They refer to previously recorded tamassuks, although there are no tamassuks extant in the collection. Two of the four Persian fārigh-khațị̂s pertain to the repayment of debts; two others relate to more complex obligations and disputes over them; the Rangri document records the payment of taxes. Fārigh-khațịis in the collection are spread out in time from the mid-seventeenth century (the beginning of emperor Aurangzeb Alamgir's reign) until the late eighteenth century, by which time the Maratha Puwar sardārs were ruling the region. 


\begin{tabular}{|c|c|c|c|c|}
\hline $\begin{array}{l}\text { Year } \\
\text { CE }\end{array}$ & $\begin{array}{l}\text { Date in } \\
\text { document }\end{array}$ & Archive & The transaction & $\begin{array}{l}\text { Linguistic or graphic } \\
\text { features }\end{array}$ \\
\hline 166o & $\begin{array}{l}\text { 10 Shaban } \\
1070\end{array}$ & $\begin{array}{l}\text { National } \\
\text { Archives } \\
\text { of India, } \\
2668 / 4\end{array}$ & $\begin{array}{l}\text { Purshottam Das chaudhri returns } \\
\text { money borrowed by his father and } \\
\text { uncle to the brothers and children } \\
\text { of Nayak Khandha. }\end{array}$ & $\begin{array}{l}\text { Persian } \\
\text { Seal of qazi } \\
\text { Some of the witness names } \\
\text { are scribed in Nagri script. }\end{array}$ \\
\hline 1710 & $\begin{array}{l}2 \text { Shawwal } \\
\text { RY } 4\end{array}$ & $\begin{array}{l}\text { National } \\
\text { Archives } \\
\text { of India. } \\
2668 / 22\end{array}$ & $\begin{array}{l}\text { Hamir Chand chaudhrī and his } \\
\text { son Nihal Chand return money } \\
\text { borrowed from Kale Afghan and } \\
\text { Ganesh Sahu to their heirs. }\end{array}$ & $\begin{array}{l}\text { Persian } \\
\text { Seal of Qazi Muhammad } \\
\text { Mustafa 'khādim-i sharīa' }\end{array}$ \\
\hline 1735 & $\begin{array}{l}2 \\
\text { Muharram } \\
\text { RY } 17\end{array}$ & $\begin{array}{l}\text { National } \\
\text { Archives } \\
\text { of India, } \\
2668 / 27\end{array}$ & $\begin{array}{l}\text { Jagannath, son-in-law of Anandi } \\
\text { and Bhagirath, receives money } \\
\text { from Hamir Chand chaudhri, their } \\
\text { employer, because of an inherited } \\
\text { deed of employment (patta-yi } \\
\text { naukrī) as well as a tamassuk, after } \\
\text { a dispute, and arbitration by local } \\
\text { officials, including the kotwāl. }\end{array}$ & $\begin{array}{l}\text { Persian } \\
\text { Main seal in Nagri, possibly } \\
\text { a Maratha mokāsadār } \\
\text { Marginal notes, including } \\
\text { witness clauses, in Nagri } \\
\text { as well as Moḍi, besides } \\
\text { Persian }\end{array}$ \\
\hline 1740 & $\begin{array}{l}1150 \text { Fasli } \\
(?)\end{array}$ & $\begin{array}{l}\text { Choudhary } \\
\text { Family } \\
\text { Collection, } \\
\text { Baḍā } \\
\text { Rāolā, } \\
\text { Dhar }\end{array}$ & $\begin{array}{l}\text { The headman Babu Khan, son of } \\
\text { Fazil Khan, is given a pharkhat to } \\
\text { the effect that he has paid in the } \\
\text { taxes as assessed and agreed. }\end{array}$ & $\begin{array}{l}\text { Rangri; written in archaic } \\
\text { Nagri script with some } \\
\text { Moḍi and some Gujarati } \\
\text { letter forms } \\
\text { Two square Nagri seals, } \\
\text { illegible }\end{array}$ \\
\hline 1785 & $\begin{array}{l}1195 \text { Fasli } \\
\& 1845 \\
\text { Samvat* } \\
\text { See } \\
\text { appendix }\end{array}$ & $\begin{array}{l}\text { Choudhary } \\
\text { Family } \\
\text { Collection, } \\
\text { Baḍa } \\
\text { Rāola, } \\
\text { Dhar }\end{array}$ & $\begin{array}{l}\text { Anwar Beg and Sayyid Azam } \\
\text { relinquish claims they had made } \\
\text { on Sahib Rai's mango trees. }\end{array}$ & $\begin{array}{l}\text { Persian } \\
\text { No seal } \\
\text { Witness clauses in Nagri } \\
\text { (and some Modii) } \\
\text { Very poor Persian writing. } \\
\text { Dates written with } \\
\text { numerals running right } \\
\text { to left }\end{array}$ \\
\hline
\end{tabular}

FIgURE 2 Five fārigh-khatțīs from the Purshottam Das collection 
Document 1, in Persian, shows that sometime in the first half of the seventeenth century, the landlords Mohan Das and his brother Chandar Bhan borrowed a sum of money from Nayak Khandha, possibly a banjāra ${ }^{40}$ or itinerant trader. ${ }^{41}$ In 166o, the successor to the title of the patriarch, Purshottam Das, undertook to partially repay the debt incurred by his father and uncle; a tamassuk worth 25 rupees still remained with the creditors. Although relatively straightforward, this was a multi-generational transaction, where the heirs' obligations to repay the debts of their ancestors were clearly shared by all parties.

Some decades after this loan had been paid off, Purshottam Das's son and grandson, Hamir Chand and Nihal Chand, took another loan from two joint lenders - a sāhu (typically, a Hindu bania) and an Afghan. This deal was based on a partnership of two archetypical moneylenders in South Asia, in which the bania and the Afghan both found it suitable to use the same documentary form to record their loan. The longer narrative in the document presents yet another multi-generational story. This time, the creditors' heirs got their act together, went through their fathers' accounts and in 1710, while war between the Marathas and Mughals raged in the background, claimed back the money owed to them by the landlords. ${ }^{42}$ Both the 1660 and the 1710 documents were sealed by a qazi, who also added a brief note in Arabic saying that an iqrār (declaration) had been recorded.

Document 3, scribed in 1735, when Maratha control over Malwa was complete, reveals that tamassuks and fārigh-khațịis could record more complex multi-generational relationships, not merely related to cash loans. In this case a man called Jagannath demanded and received cash payment from Purshottam Das's family based on two kinds of transactional relationships, which he had inherited from his mother and father-in-law. He referred both to a patta or deed of naukrī or service and also a tamassuk of qarż or debt. It is unclear to me at this point whether the qarż referred to is a separate one from the money owed due to service. In any case, the resolution and cash payment

40 I say possibly, because the word banjāra is very unclearly scribed, although the cataloguer has read it as such, and there are several references to banjāras in other parts of the collection.

41 T. Kothiyal, Nomadic Narratives: A History of Mobility and Identity in the Great Indian Desert (New Delhi: Cambridge University Press, 2016).

42 For the history of Maratha invasions of Malwa and subsequent establishment of the Maratha principalities in Central India, see S. Gordon, "The Slow Conquest: Administrative Integration of Malwa into the Maratha Empire, 1720-176o." Indian Economic and Social History Review 11/1 (1977): 1-40; R. Sinh, Malwa in Transition, First Phase 1698-1765 (Bombay: D.B. Taraporevala, 1936). 
followed a dispute, which was resolved through the arbitration of local administrative officials, including the police or kotwāl. There was no indication that an Islamic judge, or qazi, was involved in any part of the proceedings, not even the authentication of the document.

Document 4, dated 1740, is in a form of Hindi close to, but not quite Rajasthani, which Grierson called Rangri. It designates itself a phārkhatī (written in Nagri script as phārkhatī— फारखती, unlike Banarsidas's phārkatī— फारकती), and is from the period when Dhar in Malwa was under the control of the Maratha Puwar dynasty. It is something of an outlier in this set (but not among fārigh-khațịis in general), because rather than obligations towards individuals, it deals with obligations towards the state. It records that assessed taxes have been paid by Babu Khan, son of Fajil Khan of Ratnagawan, to Rajashri Pandit Gangadhar jī, son of Sadasiv jī, mokāsadār (revenue-proceeds holder, similar to Mughal jāgìrdär) of Dhar. The document bears the date 1150 Fasli, which converts to $1740 \mathrm{CE}$; there are two square Nagri seals, neither of which are legible to me beyond the Shrī. There is a short phrase written in Marathi in the Modi script, mentioning the date and Islamic month (6 Shaban), as a note next to the terminal seal. The invocation is still the Islamic 'Alif'.

The use of fārigh-khațīis to record tax payments was not new; we have seen how the Mughal businessman Banarsidas saw them in use in Bengal. Nor was the use of Rangri (or variants of what came to be called Hindi) in Maratha-ruled areas an aberration: ${ }^{43}$ decentralized Maratha rule in the mid- to late eighteenth century appear to have responded wholeheartedly to the linguistic makeup of the realm, with short notes in Marathi written in the Modi script providing a formal visual marker of Maratha imperial unity.

Document 5, which I have chosen as the illustration for this article (see Appendix), bears two dates: 1195 Fasli and 1845 Samvat, which both convert to $1785 \mathrm{CE}$. Issued in the late eighteenth century, it records a transaction between two groups of individuals, one Muslim, possibly Afghan, and the other Hindu, possibly käyastha and related to the Purshottam Das family. It records that when Anwar Beg and Sayyid 'Azam had made a claim to certain mango trees in the orchard belonging to a certain Sahib Rai, the latter had demanded to see documentary proof supporting the claim. The claimants, being unable to produce such documents, had to relinquish their claim, and make a declaration (iqrār) to that effect in the qazi's court. This relinquishing of claims was recorded in a document that designated itself a färkhațī (writtenىفارخط) which was witnessed in Nagri script by Gulab Rai, Hira Chand and Pratap

43 R. Sharma, Rājbhāshā Hindī ki Kahānī [The Story of Hindi, The Official Language] (New Delhi: Ankur Prakashan, 1980): 50-75. 
Chand (all kāyasthas and of Dhar) and by Anwar Beg and Sayyid' Azam, residents of pirān-i Dhar. The document is unsealed.

Together, these documents allow us to make some clear sociological, institutional and linguistic points about the use of farigh-khațīis in Mughal and post-Mughal central India, and also help us trace the many-faceted processes of legal translation. To begin with the sociological, in transactions recorded in documents 1,3 , and possibly 5 , we have creditors who may appear to be social inferiors advancing long-term loans to and/or asserting cash or property claims towards a significant landlord family. If we take 1, 2, 3 and 5 together, we see active use of the form across religious and caste groups-Afghans, banias, banjāras, kāyasths and landlords reveal knowledge of, and facility with using the documentary form. The documents point to a striking social range for the usage of Islamic, specifically Persian-language Islamic legal documents in Mughal and immediately post-Mughal India. All the parties in documents 1 and 3 were Hindu; the parties in documents 2 and 5 were Muslim and Hindu. While we have long been aware of the acquired fluency in Persian among scribal, administrative and courtly social groups associated directly or indirectly with Mughal and other regional Islamic kingdoms, thus far there has been very little systematic reflection on the social percolation of specifically Islamic legal forms for inter-personal transactions, which, by their nature, were more optional than interactions with the state. ${ }^{44}$ People chose to transact with each other, and in doing so, to use these kinds of legal documents, just as Farhat Hasan has shown with relation to Khambayat and Surat in the seventeenth century, where Hindu bania women used the qazi's court to resolve their inheritance disputes. ${ }^{45}$

Such choices were made even by members of nomadic communities such as banjāras, who were well-known for their computational skills but were by all accounts an illiterate people. Jagannath, too, belonged to the caste of dhangar, or shepherd, and while he sported a Persian-language seal of his own, perhaps as reflection of his retainer status, this is not conclusive evidence of his ability to read Persian, or in fact, to read at all. The context, then, suggests the possibility of a fetishistic use of Islamic legal documents written in Persian, which people may have saved and brandished periodically. This is not unlike how many people still interact with the legal system in South Asia until the present day. ${ }^{46}$

44 This is the point I made in N. Chatterjee, "Reflections on Religious Difference and Permissive Inclusion in Mughal Law." Journal of Law and Religion 29/3 (2014): 396-415.

45 F. Hasan, State and Locality in Mughal India: Power Relations in Western India, c. 1572-1730 (Cambridge: Cambridge University Press, 2006): 71-90.

46 S.N. Ghosh, "Not Worth the Paper It's Written On': Stamp Paper Documents and the Life of Law in India." Contributions to Indian Sociology 53/1 (2019): 19-45. 
The choice that such people made was of course not a free-floating decision; it was shaped by the existence of institutions where such documents would be effective, or, to see it another way, which required tamassuks and färigh-khațị̄s in order to make debt-claims legally cognizable. Perhaps the most predictable of these institutions is the qazi's court. But the documents also slipped across jurisdictions (and times) - remaining popular and effective in a Maratha regime, for Hindus (such as the dismissed servant Jagannath) as well as Muslims (the tree-deprived Anwar Beg), and in institutions other than the qazi's court.

We still know too little about the judicial systems of the Maratha Empire, ${ }^{47}$ and practically nothing about the judicial institutions in eighteenth-century Malwa, that is, Maratha realms beyond the core Marathi-writing zones. Unfortunately, I have not been able to link the principal seal in document 3 from 1735 (which records Jagannath's arrears claim on dismissal) with any known historical figure, which would have made it easier to understand the forms of judicial authority that replaced or sidelined the qazi. But we can begin to identify some patterns. The legend on the seal begins Shri Shivcharan ... and probably belonged to a Maratha official, perhaps one of the kamāvissdärs (district revenue collectors) or their office who could take cognizance of decisions taken by police-administrative officials (kotwāl). Underneath it was a note that reads: 'As written, witnessed by Naro Sivdev and Sadasiv Ram, kamāvīsdārs of district Dhar, etc. in the care of Rajashrī Anand Rao Puwar.'

Anand Rao Puwar was the Martha sardār reigning in Dhar 1732-6.48 The kotwāl was in this case playing a broader judicial role that we know the post entailed in the Maratha Empire. ${ }^{49}$ In authenticating the record of such a decision, the kamāvīsdārs, once again, were playing roles that were in evidence elsewhere in the Maratha Empire. ${ }^{50}$

Together, the kotwāl and the kamāvīsdār appear to have taken over the adjudicative and documentation roles previously performed by the qazi. These institutional changes (from Mughal to Maratha) were demonstrably not associated with a change in legal devices or in language - the Indo-Persian

47 Among the most important works are V.T. Gune, The Judicial System of the Marathas (Pune, 1953); S. Guha, "An Indian Penal Regime: Maharashtra in the Eighteenth Century." Past and Present 146 (1995): 101-26; R. O'Hanlon, "In the Presence of Witnesses: Petitioning and Judicial 'Publics' in Western India, circa 1600-182o." Modern Asian Studies 53/1 (2019): $5^{2-88 .}$

48 Chatterjee, Negotiating Mughal Law: 195-7.

49 P.L. Saswadkar, "A Note on the Kotwali of Poona in the Last Quarter of the Eighteenth Century." Proceedings of the Indian History Congress 24 (1961): 274-80.

$50 \quad$ G.C. Vad et al., ed., Selections of the Satara Rajas and Peshwas' Diaries, vol. 6/2 (Poona: Deccan Vernacular Translation Society, 1909): 271; vol. 7/2 (Poona: Deccan Vernacular Translation Society, 1911): 255-6. 
fārigh-khaț̣ị and Hindi phārkhatī continued to record release from monetary obligations, fiscal or commercial. The Maratha Empire did not summarily jettison all older Persianate documentary forms, despite the ideologically charged effort to de-Persianise official Marathi writing, represented by the royallysponsored administrative lexicon, the Räjyaryavahärakosha, produced around $1677 .^{51}$ That text, prepared under the express orders of Shivaji, the founder of the Maratha Empire, did not offer document forms as such, but only Sanskritic lexical alternatives for Perso-Arabic technical terms - being a kind of bilingual thesaurus. ${ }^{52}$ And while new documentary forms were invented and named in the Maratha Empire, these tended to be the prestige documents, so that farmāns were replaced with ājñyāpatras, arżdāshts with vinantīpatras and so on. Popular and everyday documentary forms, used for recording revenue payments and inter-personal transactions, escaped these reforms, simply because it would be irrationally expensive - in terms of effort and resources - to bring about such a wholesale transformation of writing cultures. Thus, just as they had continued in Bengal from under Afghan regimes to under the Mughals, fārigh-khațịis (and their vernacularized avatars, the phārkhatīs) continued in Malwa from the Mughals to the Marathas.

And so a Maratha kamāvīsdār gave Jagannath a standard Persian fārigh-khaț̣ī, just with Nagri seals (i.e. the prestige element). Document 4, the Hindi (Rangri) revenue receipt, may similarly have been a continuation of Mughal revenue practice, especially if we keep Banarsidas's experiences in mind. Considering the Hindi/Rajasthani document of tax receipt together with the Persian quittance deeds allows us to glimpse the range of functions and languages associated with färigh-khațtịs within a single archive, and trace the processes of continuity and change over time, and across regimes.

When we come to Document 5 from 1785 , then, we have a culmination of several processes. That it is not sealed offers the possibility that people on occasion recorded their transactions and disputes without recourse to any official at all, judicial or otherwise - as they demonstrably did even during Mughal rule. It also evidences the continued use of Persian, at least among well-heeled villagers, Hindu and Muslim, and the continued prevalence of the structure and lexicon of Mughal documentary forms. Even when rulers

51 S. Guha, "Bad Language and Good Language: Lexical Awareness in the Cultural Politics of Peninsular India, ca. 1300-180o." In Forms of Knowledge in Early Modern Asia: Explorations in the Intellectual History of India and Tibet, 1500-1800, ed. S. Pollock (Duke University Press, 2011): 41-68, at 6o-4.

$5^{2}$ For a detailed treatment of this text that goes beyond a Persian-Sanskrit binary, see Prachi Deshpande, "Documentation and Language." In Inscribing Marathi: Writing, Script and a South Asian Language in History, unpublished book manuscript, cited with the author's permission. 
changed and institutions were transformed or completely replaced, people felt that this is what a legal document looked like, and knew that they needed to create them in order to validate transactions and create cognizable records. So the fārigh-khatțī was translated in the classical Latin etymological sense-it travelled, largely untrammeled, across regimes. Moreover, despite change in institutions, it travelled with the core sense intact - it was a record of the fulfilment of monetary or monetisable obligations. It remained an active legal form, and did not become a relic. What changed was neither the word, nor the sense, but the sound: the 1785 fārigh-khaț̣ī calling itself fārkhațī, absorbing Indic phonetics into Persian. Legal documents may have looked a certain way when written out on paper, but people pronounced their names in the manner of the languages they spoke, and those sounds then trickled back into the scribes' practice.

Phärïkhat (फारीखत) in the Maratha Empire ${ }^{53}$

Even the trajectory of translation proposed above is an over-simplification. The travels and travails of the fārigh-khațți were not limited to a unidirectional geographical and temporal trajectory from the Islamic world to the Mughal Empire to the successor regimes in various regions of South Asia. Different parts of South Asia had their distinct 'Persianate' histories, and the Deccan, where the 'core' areas of the Maratha Empire were located, was one such distinctive zone. ${ }^{54}$ Thus as we move, in this section, to exploring the document called phārīkhat and its uses in the Maratha Empire, we are not just adding a postscript; we are in some ways starting another story.

The Maratha Empire arose in the second half of the seventeenth century from the cracks in the Persianised southern Indian sultanates, most importantly, Bijapur (conquered by the Mughals in 1687), and in rebellion against the incoming Mughals. ${ }^{55}$ The use of Persian in the Maratha Empire is therefore the legacy of at least two lines of development, the Deccani and the Mughal,

53 The word is spelt with a long vowel in Modi, which does not distinguish between length of vowels. By the late eighteenth century, the word had become phärkhat in Marathi, for reasons unclear to me.

54 R. Eaton, The Sufis of Bijapur, 1300-1700 (Princeton: Princeton University Press, 1978); R. Eaton, "The Rise of Written Vernaculars: The Deccan, 1450-165o." In After Timur Left: Culture and Circulation in Fifteenth-Century North India, ed. F. Orsini and S. Sheikh (Delhi: Oxford University Press, 2014): 112-29.

55 S. Gordon, The Marathas, 1600-1818 (Cambridge: Cambridge University Press. 1993); A. Wink, Land and Sovereignty in India: Agrarian Society and Politics under the Eighteenth Century Maratha Svaräjya (Cambridge: Cambridge University Press, 1988). 
which were equally well-developed and had autonomous demographic and cultural connections with Iran. ${ }^{56}$ In addition, with the vernacular millennium afoot for several centuries, Marathi (among other New Indo-Aryan languages) had been developing its own lexicon and texts from the late thirteenth century. ${ }^{57}$ Although literature-centred histories of the Marathi language see its enormous Perso-Arabic lexical component as an incursion, there may be another way of looking at this.

Sumit Guha, commenting on Maratha royal orders produced in the seventeenth and eighteenth centuries, offers an explanation for the density of Persian-derived vocabulary and conventional formulae in some parts of the documents (the opening and closing sections). Guha has suggested an active role of aural and oral processes as well as rote-learning by Marathi scribes. He has plausibly suggested that many royal orders were orally delivered, and thus, while the document might be later 'framed' with new Sanskritic formulae, the main text of the document, constructed with dictation in full flow, was inevitably peppered with Persian-derived phrases that the scribes were familiar with. ${ }^{58}$

The Persianate phrases therefore constituted the familiar in such a context, not the extraneous and intrusive, although the Marathi-writing scribes were unlikely to have been fluent in Persian. We can understand how this worked if we take insights from literary scholarship on the interaction between texts and tellings in mostly illiterate South Asian societies. For example, the Purānas, encompassing the cosmic as well as the worldly, and including the antecedents of the worthy and entitled, formed a discursive field where the Sanskrit text remained as live referent, but was constantly 'expanded' through live glosses in other languages. ${ }^{59}$ To audiences who mostly did not know Sanskrit, its sound would have produced the aura of authenticity for the vernacular (oral) text that followed, but for those who knew both Sanskrit (and Marathi, say), the text and the oral rendering were in fact meaningfully related. Could Persian have had a similar relationship with Marathi in legal documents?

We may see this happening even more starkly with lower-level (i.e. non-royal) documents, recording transactions between relatively ordinary, if substantial villagers. In this section, we look at such Marathi documents, derived from

56 E.J. Flatt, The Courts of the Deccan Sultanates: Living Well in the Persian Cosmopolis (Cambridge: Cambridge University Press, 2019).

57 Eaton, "The Rise of Written Vernaculars": 114.

$5^{8}$ S. Guha, "Mārgī, Deśi and Yāvañ̄": 140. Also see Anuradha Kulkarni, Shivchhatrapatichi Patre, vol. 1 (Mumbai: Param Mitra Publications, 2011): 2-3, where we see Persian all over-so a 'slipping back.'

59 R. O'Hanlon, "Performance in a World of Paper: Puranic Histories and Social Communication in Early Modern India." Past and Present 219 (2013): 87-126. 
published and unpublished collections of Marathi (and bilingual PersianMarathi) documents that are prolific thanks to the efforts of the activist Marathi historians of the early twentieth century.

With such documents, it is difficult to undertake the kind on in-the-archive analysis used for the Purshottam Das collection. This is because activist scholars of Maratha history (quite like those of the Mughal Empire) who acquired such documentary collections disaggregated them based on their research interests, and their Marathi ethno-linguistic nationalism. Little to no accession history was retained, so the archival provenance of the documents is often a blur; the collections are generally 'purged' of extraneous, i.e. Persian, materials; and little information is preserved regarding the graphic and material features of the documents.

Nevertheless, looking closely at some of these collections suggests that several derive from the archives of landed families that were very similar to the Purshottam Das collection from Malwa. One such unpublished collection of documents is that of the Solapur deshmukhs, currently held at the Bharat Itihas Sansodhak Mandal at Pune. The Solapur deshmukhs were a Lingayat lineage, equally involved in trade and in state offices associated with landholding. The collection, acquired by the historian G.H. Khare in the 1950s, contains nearly 2,0oo documents, of which the majority are in Marathi, written in the Modi script, and a significant minority are bilingual (Persian and Marathi). There are witness clauses in Kannada in some of the documents. ${ }^{60}$

In a document written in Marathi (in Modi script) in 1719-20, a village headman (muqaddam) called Manaji recorded that he was renouncing his claims to certain wells. The qazi noted briefly, in Persian, that an iqrār by the muqaddam had been recorded and sealed. Rather unusually, the qazi noted himself in his seal as the servant of an official called Khudavand Khan. (Qazis' seals from the Mughal Empire generally noted that they were servants of the law of Muhammad, not any specific noble or king.)

A comparable collection of documents was procured by the Marathi historian Oturkar from Sasvad, from the household $(w \bar{a} d \bar{a})$ of the PurandaresBrahmin officials closely associated with the Peshwas, themselves Marathi Brahmin ministers-turned-emperors of the eighteenth century. ${ }^{61}$ The Purandares may have had access to these documents because they held heritable

6o D. Vendell, "Market Governance and Social Plurality in Seventeenth-Century Western India," conference paper, European Social Sciences History Conference, Leiden, March 2021, mss with author; G.S. Khare, "The Archives of the Deshmukh Family of Sholapur (Bombay)." Proceedings of the Indian History Congress 16 (1953): 273-5.

61 Sasvad, a few miles south-east of Pune, was the original home-town of the family of the Peshwas themselves. Imperial Gazetteer of India, vol. 12 (Oxford: Clarendon Press, 1908): 
administrative office at both the level of the locality and the district (kulkarni and deshpannde), and thus performed major roles in authorizing and managing documentation of transactions. In certain documents, they are clearly noted as the writer with the word dastkhat (in Marathi usage: by the hand of, rather than 'signature') preceding their names at the bottom of the page. It is likely that, as an extension of all these tasks, they also served as a repository of information, whether or not this was part of their official portfolio.

In the Purandare's collection there is a Marathi document dated 1666 Shaka ${ }^{62}$ (1744 CE), called a 'phārīkhat'. The document states that three individuals, Naikbai Jagthap, Ranoji Jagthap and Miwai Jagthap, had spent ten or fifteen years with the Gosain (monk) Udaigiri of the temple of Sidoba (another name for Siva), and may therefore have some of the Gosain's goods and money in their possession. With this document, the Gosain released them from all monetary obligations towards himself, and as a guarantee against future senility and greed, added that if he reneged from this requital, he would have a 'shoe on his face' as well as his father's face, i.e., would be dishonoured. ${ }^{63}$

The Jagthaps were a major Maratha (therefore, non-Brahmin) landholding warrior clan, with a cluster of families in Sasvad, the Purandare's stronghold. Today they claim ancient Hindu royal lineage as well as association with Shivaji during the establishment of the Maratha Empire. The only major temple in Sasvad — the Samgameshwar temple—is dedicated to Sidoba. ${ }^{64}$ One can only speculate what kind of social interactions, patterned or exceptional, may have led brought a girl and two boys, possibly as orphans, into the care of this monk of a major temple. Perhaps the Jagathap family had a tradition of dedicating some children for service to the temple; or maybe this was an orphaned set of children whom the Gosain had brought up, perhaps he was clearing off all future entanglements in his old age, or even on his deathbed. The document was signed by five headmen ( $p \bar{a}$ țils and deshmukhs), two of them Jagathaps, and one Gosain of another mața (monastery) of Nagareshwar. Above all, the document was said to be in the signed by the very hand of Sadashiv Purandare Deshpande Kulkarni, indicating quite clearly, in this case, that this document

112; also see B.G. Gokhale, Poona in the Eighteenth Century (Delhi: Oxford University Press, 1988): 116-7.

62 R. Salomon, Indian Epigraphy: A Guide to the Study of Inscriptions in Sanskrit, Persian and Other Indo-Aryan Languages (Oxford: Oxford University Press, 1998): 182-4.

63 R.V. Oturkar, ed., Peshwekalin Samajik Va Arthik Patra Vyavahar 1722-1854: Swiya Granthmala No. 79, (Pune: Bharat Itihas Sanshodhak Mandal, 1950): 90.

64 For the pastoral deity Sidoba/Siddheshwara's connection to Shiva, see Günther-Dietz Sontheimer, Pastoral Deities in Western India, trans. Anne Feldhaus (Oxford: Oxford University Press, 1989), 22-30. 
had formed part of the collection because a member of the Purandare family had been directly involved - in witnessing, or perhaps authorizing the transaction.

Perhaps the most dramatic of Marathi phārīkhat documents is referred to in a letter written in 1795 by Govindrao Krishna Kale, the Peshwa's envoy to Hyderabad. ${ }^{65}$ Govindrao reported how certain Afghan soldiers, employed and dismissed by Ihtesham Jung Nasir al-daulah, ${ }^{66}$ turned up at his household, accosted his eleven-year-old son who was practising Persian in his father's diwān-khāna, and demanded a phārikhat. When the boy protested that he was a mere child and attempted to leave, the soldiers stabbed him. The noble in question predictably had the Afghans chopped to pieces; the Nizam himself sent over money and provisions for the injured boy's treatment. ${ }^{67}$ As Fahad Bishara's article in this collection shows, floating labourers required release documents in order to be employable; military labourers in India could kill to get them.

Marathi phārīkhats could even encompass matrimonial issues. A study of Pune kotwāli records from the late eighteenth century shows a documentary form called phārīkhat being used to record divorces. ${ }^{68}$ Two instances recorded include a phārīkhat issued by a caste council (jātī panchayat) allowing separation of a young wife from her impotent husband; 69 and a phārikkhat of separation given by a husband who later attempted to retract it (leading to an investigation by the kotwāl). To complicate matters further, the first document is said to be in Gujarati script; Gujarat in the early nineteenth century saw full-blown development of the use fārigh-khațịis for divorce. Strikingly, these documents were structurally and lexically almost identical to the commercial ones we have seen so far. Elizabeth Lhost powerfully argues that such

65 For his career at Hyderabad, R. O'Hanlon, "Entrepreneurs in Diplomacy: Maratha Expansion in the Age of the Vakil." Indian Economic and Social History Review 57/4 (2020): 524-30; J.G. Duff, A History of the Mahrattas, vol. 3 (Calcutta: R. Cambray \& Co., 1918): 106$7,110$.

66 Probably Ihtesham Jung, the son of Ibrahim Beg Dhaunsa Zafar ud-Daula. The latter was a Turkish soldier who became the ruler of the small principality of Nirmal under the Nizam. His son, Ihtesham Jung, rebelled and so was transferred to the Berar subahdar post at Ellichpur. Dominic Vendell discusses these figures in the context of Maratha-Nizamate joint rule of Berar province in his "Scribes and the Vocation of Politics, 1708-1818," unpublished PhD thesis (Columbia University, 2018): 71, 76-7.

67 V.K. Rajwade, ed., Marāṭ̂āanchyā Itihāsāchī Sādhane, vol. 5, online edition, no. 30, p. 39 (http://samagrarajwade.com/index.php/marathyanchya-itihasachi-sadhane-khand-1/ marathyanchya-itihasachi-sadhane-khand- 5 ? start $=38$ ).

68 N.K. Wagle, "The Government, the Jāti and the Individual: Rights, Discipline and Control in the Pune Kotwal Papers, 1766-1794." Contributions to Indian Sociology 34/3 (2000): 321-6o.

69 Wagle, "The Government, the Jati, and the Individual": 331. 
usage designates an open-ended use of Islamic legal forms (across religious communities and across social registers) that became increasingly constricted and confessionalised (Islamised) as, ironically, British legal systems were institutionalized. ${ }^{70}$

Let us now pause and compare Document 3 from 1735 (Jagannath's claim and quittance deed) with the Marathi documents we have just discussed. Jagannath's deed was in Persian, but it was a document of the Maratha Empire too. So what is the pattern of translation?

Descriptively, the Marathi phārikhats from Pune, Sasvad and Solapur are in many ways similar to the Mughal-Persian fārigh-khațīis. The essential structure of the document is retained: naming the parties, reciting the relevant antecedents that had built up monetary obligations, a declaration of the annulment of these, and a securing clause (which could be curses). Phrases derived from Persian continued to be used - but frequently in etymological translation-e.g. bä'iș-i tahrir (reason for writing) was replaced with lyāhāvayā kāraṇē; note here that this lexical approach was very much the recommended strategy of the Räjryavahärakosha. On the other hand, some elements, clearly considered untranslatable, continued, such as the combination of Islamic months and regnal year, sometimes combined with the distinctively Dakhni-style Shaka and Brhaspati calendars. ${ }^{71}$

The most remarkable change was in the prestige elements: god was invoked differently (Shrī, instead of Allah); seals were infrequent (although this is hard to establish without access to the original documents); and use of earthy promissory clauses/injunctions abounded. As we have seen, one document noted that any deviation [from the terms of document] would entail dishonor to the writer in the form of a 'shoe on his face' and his father's, too.

No qazi, nor any other kind of specialised judicial official was involved in Sasvad and Pune, but the Solapur document was sealed by a qazi. The other authorities involved were landlord-cum-officials in their adjudicative roles, and caste councils.

Why did caste councils and other Maratha authorities accept or require phārikhats? It seems to me that this is because of a number of reasons:

70 E. Lhost, "Writing Law at the Edge of Empire: Evidence from the Qazis of Bharuch (1799-1864)." Itinerario 42/2 (2018): 263. And a fuller description in E. Lhost, "Between Community and Qānūn: Documenting Islamic Legal Practice in Nineteenth-Century British India," unpublished PhD thesis (University of Chicago, 2017): 224-39.

71 R. Salomon, Indian Epigraphy: A Guide to the Study of Inscriptions in Sanskrit, Prakrit, and the Other Indo-Aryan Languages (New York: Oxford University Press, 1998): 182-4, 197. 
the Maratha Empire had risen in a Persianate sub-zone that long pre-dated the Mughals; phārikhats were among legal forms long known to the populace therein and to the landed gentry who manned the Maratha Empire's administration; the regime had not bothered to change or replace these forms. Therefore, when people in the Maratha Empire, or the scribes they hired, set out to record key transactions, they recalled Persian-derived phrases and forms, and retained the core concepts associated with these forms. They then glossed out the key legal elements in fairly simple Marathi, as the Puranic performers did with their tattered Sanskrit texts.

\section{Mughal Documents in British-Ruled Bengal}

This phenomenon of formal, aural, and conceptual-if not doctrinalfamiliarity with Persianate legal forms keeps reappearing if we follow the travels of tamassuk and its twin fārigh-khațīi beyond the realms of Indian empires. Moving a century ahead in time, we find that in a revered colonial dictionary published in 1855 , compiled by the Sanskritist Horace Hayman Wilson, ${ }^{72}$ färigh-khaț̣ī is glossed in this way:

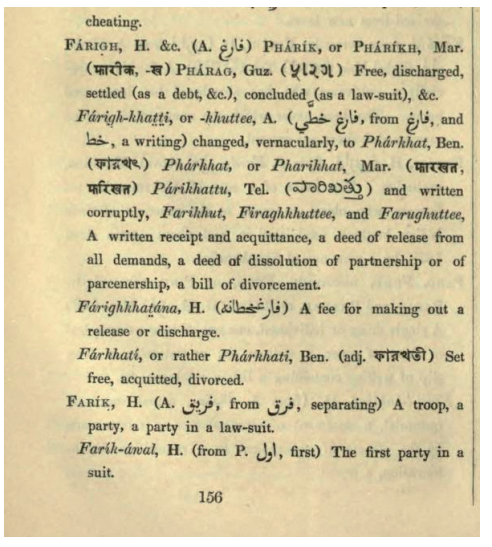

FIGURE 3

Entry for fārigh-khaț̣īi in a colonial dictionary

As this entry shows, the concept and the documentary form of fārigh-khatți was still recognisable in the mid-nineteenth century as related to its Mughal precedents, that is as a 'deed of release from all claims', but, especially in its

72 H.H. Wilson, A Glossary Judicial and Revenue Terms (London: W.H. Allen, 1855): 156. Several other colonial glosses offer similar definitions. 
phonetically vernacularized forms, it could now also be a deed of divorce (as we have already seen). The word and form had travelled into at least four languages, namely Hindi, Marathi, Bengali and Telugu; we also have evidence that it had made its way into Rajasthani and Gujarati.

In this section, we look at a genre of Bengali books known as patra-kaumudī (literally: moonlight on letters/deeds; epistolaries), which was very popular when printing took off in India in the early nineteenth century. ${ }^{73}$ Several works produced in this genre were clearly intended as didactic tools as well as practical manuals, and these pedagogic efforts were intrinsically linked to the formation and entrenchment of the East India Company government in eastern India. In 1822, J.D. Pearson, Superintendent of the Company's Bengali schools, produced a Bengali book for the Calcutta School Book Society called the Potro-cowmoodee pathshālar nimitte; or, book of letters, \&c. containing letters of correspondence, commercial and familiar with zumeendaree and other legal forms. ${ }^{74}$ Several versions with similar titles, produced by various individuals and institutions, are extant in libraries across West Bengal (India) and Bangladesh. In an explicit aim to assert Indic (rather than Islamic or Persianate) antiquity, these books claim to be translation of a thirteenth-century text produced by a certain Vararuci, courtier of the legendary king Vikramaditya. However, as the 1822 edition's title clarified, the bulk of the documents dealt with very contemporary institutions and concerns, such as the colonial form of the zamindāri (landlord) title, and the procedures of colonial courts.

In these books, tamasuks (তমসুক) and phärkhats (ফারখৎ) were regular fixtures. A publication titled pāthshāla-paddhatī (primer), which I found in Chittagong University Library with the publication details missing, ${ }^{75}$ teaches fairly complex calculations as well as the drafting of legal documents. One such entry is on "tamasuk" - beginning with the gloss "The document for accepting debts is called tamasuk." This model document begins with an eclectic language that has been judged unlovely with the rise and persistence of linguistic purism since the early nineteenth century, but which reveals the intricate ways in which terms and concepts travel in a multi-lingual terrain.

The initial portion of the model Bengali tamasuk document, preceding the section marker ' $\bar{a} g \vec{e}$ ( which one also finds in Rajasthani and Hindi documents),

73 U. Stark, An Empire of Books: The Naval Kishore Press and the Diffusion of the Printed Word in Colonial India (Ranikhet: Permanent Black, 2007). There was an earlier spate of printing, undertaken mainly by European Jesuit missionaries; there was no indigenous knock-on effect of that process.

74 J.D. Pearson, Potro-cowmoodee (Calcutta: School Book Society, 1822).

75 Anon., Pāthśála Paddhatī (no publication details), Chittagong University Library. 
is a linguistic mixture that is a lexical and grammatical delight (or horror, depending on taste), but it is the whole that is legally meaningful.

Yād kïrdda Shrī Golak Chandra Mahajan pisāre Ramkrishna Mahajan mrta sākin pahartali sthāne likhitam Shrī Harihar De pisāre Brindaban De sākin unashattar pāra ... kasya karjja tamasuk patra midam àgē ...

(It is recorded that: Shrī Golak Chandra Mahajan, son of Ramkrishna Mahajan, deceased, resident of Pahartali, it is written [that]: Shrī Harihar De, son of Brindaban De, resident of neighbourhood $69 . .$. for his debt [a] tamasuk deed is given, thus ...)

The words in bold in this excerpt are either unaltered or minimally altered Persian words (pisāre=son of; sākin=resident; karjja=qar $\dot{z}=\mathrm{debt}$ ); Sanskritic Bengali equivalents of Persian words ( $m r t a=m a r h u \bar{m})$ are used in the Marathi etymological translation style. In other cases, creatively corrupted Persian words or phrases, phonetically assimilated to Sanskrit, are used-creating a lexicon of false tadbhava words. These are not real Sanskrit words or their derivatives ( $y \bar{a} d$ kìrdda=recorded, midam a $\bar{g} \bar{e}=$ middahand $\bar{a} n k a=i s$ given that), but they sound like it. The rest of the document is a straightforward plainBengali description of the amount and duration of the loan, the terms of return and interest payable on default. The scribe is named at the bottom of the documents as mucchuddī (Persian=mutașaddī).

Where Zatalli's spoof tamassuk used the hollowed out but perfect form to present an implausible transaction as a joke, the Hindi, Marathi and Bengali tamassuks/tamasuks and phārkatī/phārkhatīs/phārīkhats were real documents or models thereof, intended to record substantive obligations and release therefrom. In this case, the form and its vocabulary underwent what I think is phono-semantic matching (PSM), such that unfamiliar words are lexically assimilated by altering their pronunciation to match familiar soundscapes. It is striking that, in the Bengali case, such PSM included not just alignment to Bengali phonetics but also to Sanskrit, the anusvaras or 'am' endings producing a pseudo-Sanskritic feel that people clearly felt necessary to record a formal transaction.

Even colonialism then, had failed to destroy the familiarity of Perso-Islamic legal documents in South Asia. It had merely opened up further institutions which accepted, nay, required and solicited documents such as the fārigh-khaț̣ị in order to legalise the secure ending of contractual relationships and of mutual obligations. 


\section{Conclusion}

The law may be an ass, as Mr Bumble suggested, but was it all just windowdressing? It is worth summarising, and limiting the arguments of this article for the reader uncomfortable with what might appear to be an utter dismissal of legal doctrine in favour of unthinking 'practice.'

This article has presented an early modern South Asian landscape awash with Persian and Persianate legal documents, from late Mughal times until the beginning of formal colonial rule. It has demonstrated the connection between certain documentary forms popular in South Asia, and pan-Islamic legal forms. On the other hand, it has argued that distinctively Indo-Persian documentary types derived conventions, models and usage also from royal and noble writing establishments, tax departments and deep-seated community practices. The twinned tamassuk and fārigh-khatțī have been used as exemplars, to demonstrate the pervasiveness and persistence of Perso-Islamic legal forms in South Asia and to argue for the persistence of core meaning across the process of translation. People's familiarity with these forms was so great and so persistent that no matter the change of regimes, official laws, prestige languages, and even social contexts, when thinking of obligations and fulfillment, South Asians thought of tamassuk and fārigh-khațțis, and they thought of them in ways that would have been comprehensible to Muslims in the early day of Islam in West Asia and North Africa.

In the eighteenth and early nineteenth centuries, tamassuks and fārighkhaț̣īs, that twinned documentary pair for recording obligations and their fulfillment, were being produced in Marathi, Hindi, Rajasthani, Gujarati and Bengali. Unlike Zatalli's joke, which we opened with, these were functional and valid legal documents-used principally for financial, including fiscal, transactions, but in some cases, also marital relations that included monetary obligations. There were lexical and phonetic changes (such that the fārighkhațțī, became the more Indic-sounding phārkhatī, for example), but the core meaning of these documents remained remarkably stable across these multiple political, temporal and linguistic domains. The fārigh-khaț̣ī was translated, in the classical Latin sense of being moved across.

Such legal translations did not even end with the advent of colonialism. In Bengal, in eastern India, the earliest region to experience colonial rule, Persianate documentation continued to be produced, consumed, circulated and presented in colonial court rooms. Here a compilation of frequently used legal documents reveals the vast underbelly of colonial law where South Asians continued to think and transact in Persianate legal categories. It is through 
that colonial window that we also see how far the process of indigenization of Persian had proceeded, such that, in attempting to produce the most fool proof legal contract, Bengali scribes produced a Bengali-language tamassuk that included literally meaningless but semantically loaded opening formulae in Sanskritised Persian in order to produce the most authoritative sound there could be for an Indian.

This is not a story that dismisses the significance of legal doctrine, but it does query a vision of law that derives from a body of abstract and exhaustive jurisprudence that is actuated in an institutional system that is wholly congruent with that jurisprudence. It is my suspicion that such a vision of law-while attractive to jurists (and to those that study them) — has not existed anywhere in the world, at any time. In this article, I argue that, if we are to understand how people think in and about law, it is worth proceeding from the documents they produce and/or consume in order to express their immediate claims. Doing so allows us to build upwards from the ground level of history, and understand processes such as the vernacularisation of Islamic law (or, indeed, English law) and the actuation of Persianate culture. The point here is not that just South Asians from the seventeenth until the twentieth century kept using the same kinds of legal documents for everyday transactions regardless of regime, or doctrine. They did, and they were also pushed in that direction by regimes that adapted and adopted the same forms, but in doing so users of legal forms such as the tamassuk and färigh-khațīi reveal to us a subaltern and durable understanding of law. In this South Asian understanding, Perso-Islamic legal vocabulary was naturalised to the extent that its confessional genealogy was forgotten (or never known), but the core ideas endured.

Finally, this article has explored etymologies and other intellectual and institutional genealogies, but it rejects these as explanations for why documents such as the tamassuk and fārigh-khatțī were used by South Asians. This is not a story of the 'pursuit of Persian' nor of the 'vernacularisation of Islam.' It is a story of the familiar and the everyday in early modern South Asia; I argue that Persian and Islam constituted that everyday. That everyday was not idyllic; we just need to remember Zatalli's acid commentary on the disconnect of papereality from the substance of social life. ${ }^{76}$ Even so, it was the mongrel language of law that provided Zatalli with fodder for his farce, and his audience with a vocabulary of rights; to understand materials written in that language, we need to discard a search for origins, and embrace impurity.

76 B. Raman, Document Raj: Writing and Scribes in Early Colonial South India (Chicago: University of Chicago Press, 2012). 


\section{Appendix}

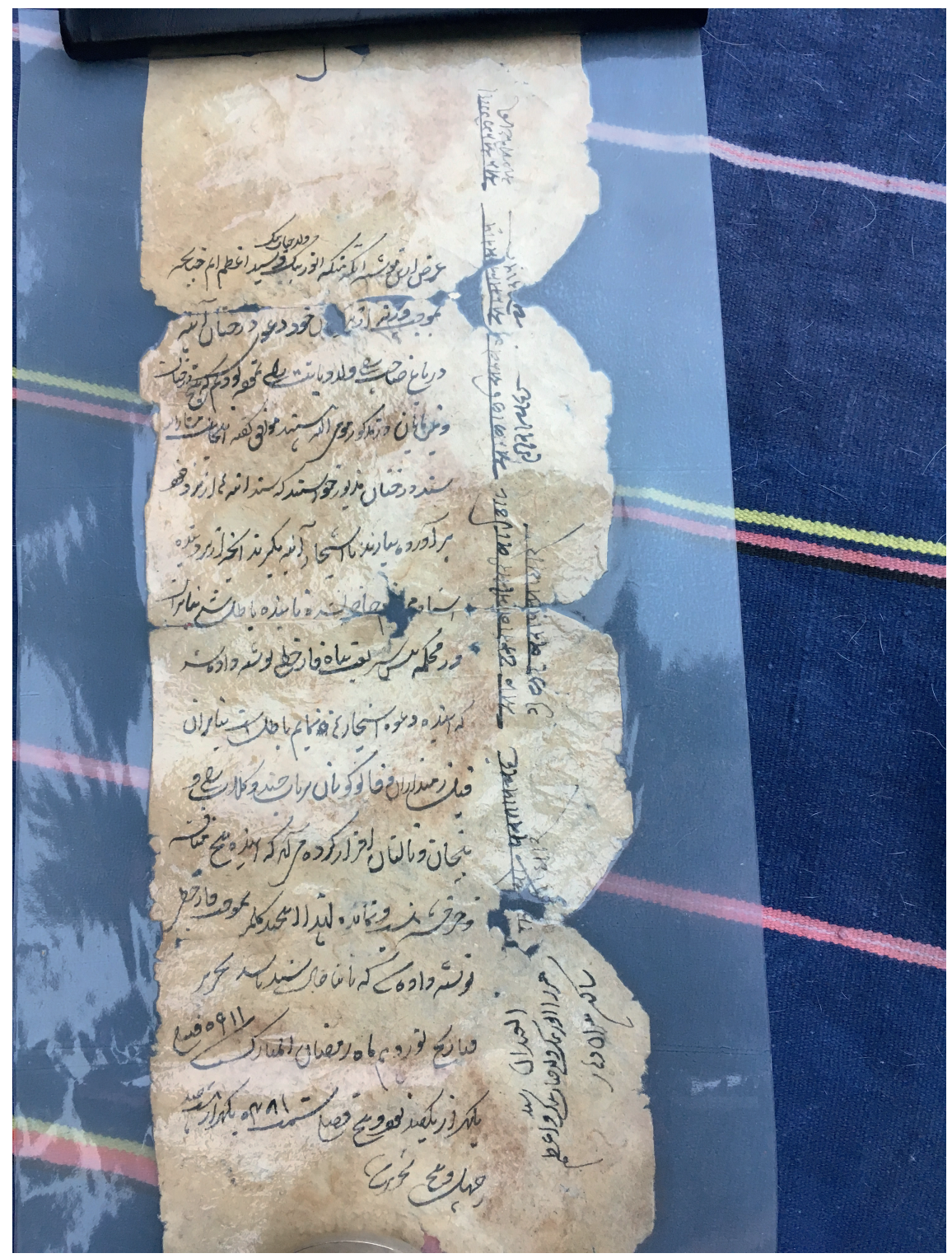

FIGURE 4 A fārigh-khaț̣ī from the Choudhry Family Collection, Baḍā Rāolā Dhar Note: Inexpensive paper, damaged at the edges and in one place within the text. 


\section{Transcription}

$$
\begin{aligned}
& \text { غرض از إن نوشته آنكه منكه انور بيك ولـ حيات بيك و سيد اعظم ايم } \\
& \text { حنا: } \\
& \text { كوجب ورثثه [...]77 خود دعوى درختان آنها78 } \\
& \text { در باغ صاحب راى ولد ديانت راى نموده بوديع كم تيخ درختان } \\
& \text { و [...] مايان در مذكور مومن اليه هستند موافت كفته اينجانب مشاراليه }
\end{aligned}
$$

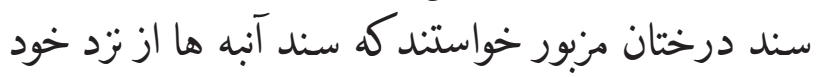

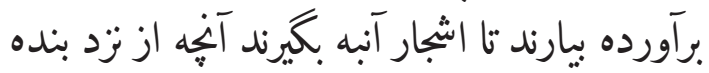

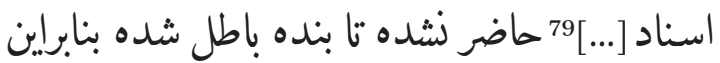

$$
\begin{aligned}
& \text { در محكمه يِش شريّت يناه فارخطى نوشته داده شد }
\end{aligned}
$$

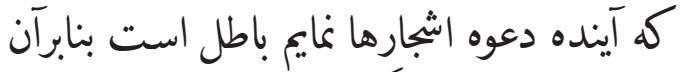

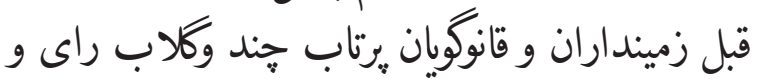

$$
\begin{aligned}
& \text { [.... [و [...] اقرار كرده مى آيد كآ آينده هيج مناقشه } \\
& \text { و خرخشه نيست و نمانده لهذا ايتهند كله بموجب فارخطى }
\end{aligned}
$$

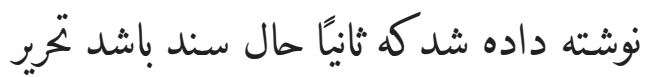

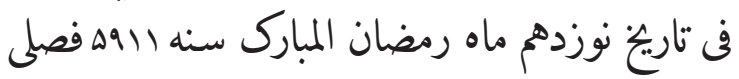

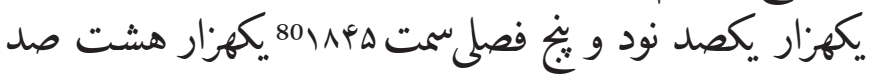

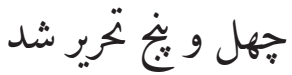

\section{Marginal notes (witness clauses):}

From top to bottom

सा(क्षी) ...

सा( क्षी) ...

\footnotetext{
$77 \quad$ Illegible because of the page damage.

78 The standard Persian spelling is i

79 Unsure reading, followed by an illegible word because of the page damage.

8o In the document, the direction of the numerals is from right to left.
} 
सा(क्षी) ...लाल हीराचंदु

सा(क्षी) ठकरानी मीसरी बाई ... गुलाब राय प(रगना) धार

चौ(धरी) परतापचंदु धार

2) (bottom-right):

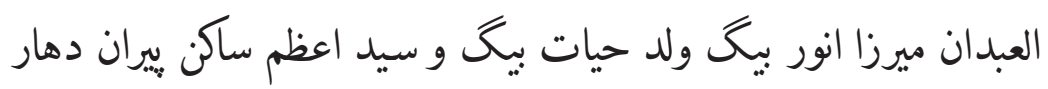

Translation

Invocation: Alif [possible abbreviation for Bismillah: in the name of God]

The reason for writing this text is this, that we, Anwar Beg, son of Hyat Beg, and Saiyid'Azam

Had made a claim, based on documents/inheritance rights [reading unclear here] to mango trees

In the garden of Sahib Rai, son of Dianat Rai, that five trees

And [illegible] are ours. As said, the said person [Sahib Rai]

Asked to see the document. [He said] that [if] we

Brought the documents, we could take the trees. Since

The documents could not be presented, our claim was voided. On the basis of this,

In the court of the qazi [Islamic judge], a fārkhați [no-claims deed] was written and given

That if we make any claims to the trees in future, it will be void. On this basis, In front of landlords and record-keepers and Pratap Chand and Gulab Rai and [name illegible] and [name illegible] an iqrār [binding declaration] was made that henceforth there is no quarrel

Nor will it remain. Therefore, these few words were written as a färkhatì [noclaims deed]

That it be a record for the future. Written on 19 Ramżān Mubārak, 1195 Faslī

One thousand nine hundred and five Fașlī, Samvvat 1845, One thousand eight hundred

Forty-five.

Marginal notes (witness clauses):

Witness: ...

Witness: ...

Witness: ... Lal Hira Chand

Witness: Thakurani Misri Bai ... Gulab Rai district Dhar

Witness: Partap Chand Dhar

Witness: The slaves Mirza Anwar Beg son of Hyat Beg and Saiyid Azam, residents of Piran-i Dhar

Verso: Not provided 


\section{Acknowledgements}

I am grateful to the European Research Commission and the Lawforms project which provided funding for the research presented in this article. I thank the participants of the 'Transactions and Documentation' workshop held in Exeter 2018, my colleagues on the Lawforms project, and the three anonymous reviewers, who helped me shape my arguments. Significant portions of this article, especially those dealing with Marathi materials, have been written in collaboration with Dominic Vendell, but he does not wish to be named as a co-author. My gratitude towards and admiration for him are enormous. All errors are of course mine. I thank the European Research Commission and the Lawforms project for providing funds to publish this article, and the entire issue, in Open Access format.

\section{Bibliography}

\section{Primary Sources}

Al-Marghinani. 1791 (12th century CE). Hedaya, trans. Charles Hamilton. 4 vols (vol. 3). London: T. Bensley.

Anon. Pāthshāla paddhatī (no publication details, possibly early 2oth century CE). Chittagong University Library.

Anon. 2007 (8th-15th centuries CE). Lekhapaddhatī: Documents of State and Everyday Life from Ancient and Early Medieval Gujarat, ed. Pushpa Prasad. New Delhi: Oxford University Press.

Banarsidas. 1981 (c. $1641 \mathrm{CE}$ ). Half a Tale: A Study in the Interrelationship between Autobiography and History [Ardhakathānaka of Banarsidas], trans. and ed. M. Lath. Jaipur: Prakrit Bharati Sansthan.

Burhanpuri, Sheikh Nizam et al. n.d. (1692). Fatāwa-yi'Alamgïrü., trans. Maulana Saiyid Amir Ali. 10 volumes. Lahore: Maktaba Rahmaniyah.

Gawan, Mahmud. 2002 (1475-6). Manāzir al-Inshā', ed. Ma‘asuma Madankan. Tehran: Fahrangistan.

Imperial Gazetteer of India. 1908. Oxford: Clarendon Press, vol. XXII.

Kambuh, Harkaran. 1781 (17th century CE). Forms of Harkaran, ed. Francis Balfour. Calcutta.

Khan, Geoffrey. 1993. Arabic Legal and Administrative Documents in the Cambridge Genizah Collections. Cambridge: Cambridge University Press.

Oturkar, R.V., ed. 1950. Peshwekālīn Samājik Va Ārthik Patra Vyavahār 1722-1854: Swiya Granthmala No. 79. Pune: Bharat Itishasa Samsodhak Mandal. 
Rajwade, V.K., ed. 1898-1926. Marāṭ̂hyānchyā Itihāsāchī Sādhane. 22 volumes. http:// samagrarajwade.com.

Shakeb, M.Z.A. 1977. Mughal Archives. Hyderabad: State Archives.

Vad, G.C. et al., ed. 19o9-11. Selections of the Satara Rajas and Peshwas' Diaries, vol. 6-7. Pune: Deccan Vernacular Translation Society.

Wilson, Horace Hayman. 1855. A Glossary Judicial and Revenue Terms. London: W.H. Allen.

Zatalli, Mir Ja'afar. 2001 (c. 1707 CE). Zatal-Nama (Kulliyat-i Jaffar Zatalli). New Delhi: Anjuman-i Taraqqi-yi Urdu.

\section{Secondary Sources}

Alam, Muzaffar and Sanjay Subrahmanyam. 2004. The Making of a Mūnshī. Comparative Studies of South Asia, Africa and the Middle East 24/2: 61-72.

Ayoub, Samy. 2016. "The Sulțān Says": State Authority in the Late Hanafĩ Tradition. Islamic Law and Society 23/3: 239-78.

Bellenoit, Hayden. 2014. Between Qānūngōs and Clerks: The Cultural and Service Worlds of Hindustan's Pensmen, c. 1750-1850. Modern Asian Studies 48/4: 1-39.

Bishara, Fahad Ahmad. 2017. A Sea of Debt: Law and Economic Life in the Western Indian Ocean, 1780-1950. Cambridge: Cambridge University Press.

Chatterjee, Kumkum. 2010. Scribal Elites in Sultanate and Mughal Bengal. Indian Economic and Social History Review 47/4: 445-72.

Chatterjee, Nandini. 2014. Reflections on Religious Difference and Permissive Inclusion in Mughal Law. Journal of Law and Religion 29/3: 396-415.

Chatterjee, Nandini. 2016. Mahzar-namas in the Mughal and British Empires: The Uses of an Indo-Islamic Legal Form. Comparative Studies in Society and History 58/2: 379-406.

Chatterjee, Nandini. 2020. Negotiating Mughal Law: A Family of Landlords Across Three Indian Empires. Cambridge: Cambridge University Press.

Daaïf, Lahcen. 2014. La Barā'a: Réflexions sur la Fonction et L'évolution de la Structure de la Quittance. Annales Islamologiques 48/2: 3-6o.

Datla, Kavita. 2013. The Language of Secular Islam: Urdu Nationalism and Colonial India. Hyderabad: Orient Blackswan.

Deshpande, Prachi. Inscribing Marathi: Writing, Script and a South Asian Language in History, unpublished book manuscript.

Dhavan, Purnima. 2019. Persian Scholarly Networks in Mughal Punjab. In The Persianate World: The Frontiers of an Eurasian Lingua Franca, ed. Nile Green. Oakland: University of California Press: 159-73.

Eaton, Richard. 1978. The Sufis of Bijapur, 1300-1700. Princeton: Princeton University Press. 
Eaton, Richard. 2014. The Rise of Written Vernaculars: The Deccan, 1450-165o. In After Timur Left: Culture and Circulation in Fifteenth-Century North India, ed. Francesca Orsini and Samira Sheikh. Delhi: Oxford University Press: 112-29.

Eaton, Richard. 2019. India in the Persianate Age, 1000-1765. Berkeley: University of California Press.

Ernst, Carl. 2003. Muslim Studies of Hinduism? A Reconsideration of Arabic and Persian Translations from Indian Languages. Iranian Studies 36/2: 173-95.

Faruqi, Shamsur Rahman. 2008. Burning Rage, Icy Storm: The Poetry of Ja'far Zatalli, unpublished lecture. University of Texas-Austin. http://www.columbia.edu/itc/ mealac/pritchett/oofwp/srf/srf_zatalli_20o8.pdf.

Flatt, Emma J. 2017. Practicing Friendship: Epistolary Constructions of Social Intimacy in the Bahmani Sultanate. Studies in History 33/1: 61-81.

Flatt, Emma. 2019. The Courts of the Deccan Sultanates: Living Well in the Persian Cosmopolis. Cambridge: Cambridge University Press.

Ghosh, Sreemoyee Nandini. 2019. Not Worth the Paper It's Written On: Stamp Paper Documents and the Life of Law in India. Contributions to Indian Sociology 53/1:19-45. Gokhale, B.G. 1988. Poona in the Eighteenth Century. Delhi: Oxford University Press.

Gordon, Stewart. 1977. The Slow Conquest: Administrative Integration of Malwa into the Maratha Empire, 1720-176o. Indian Economic and Social History Review 11/1: 1-40.

Gordon, Stewart. 1993. The Marathas, 1600-1818. Cambridge: Cambridge University Press.

Grant Duff, James. 1918 A History of the Mahrattas, vol. 3. Calcutta: R. Cambray \& Co.

Green, Nile, ed. 2019. The Persianate World: The Frontiers of an Eurasian Lingua Franca. Oakland: University of California Press, 2019.

Guha, Sumit. 1995 An Indian Penal Regime: Maharashtra in the Eighteenth Century. Past and Present 146: 101-26.

Guha, Sumit. 2008. Mārgī, Deśī and Yāvanī: High Language and Ethnic Speech in Maharashtra. In Marga: Ways to Liberation, Empowerment and Social Change in Maharashtra, ed. M. Naito, I. Shima, and H. Kotani. New Delhi: Manohar: 129-46.

Guha, Sumit. 2011. Bad Language and Good Language: Lexical Awareness in the Cultural Awareness of Peninsular India, ca. 1300-180o. In Forms of Knowledge in Early Modern Asia: Explorations in the Intellectual History of India and Tibet, 1500180o, ed. Sheldon Pollock. Durham: Duke University Press: 49-68.

Hakala, Walter. 2016. Negotiating Languages: Urdu, Hindi and the Definition of Modern South Asia. New York: Columbia University Press.

Hallaq, Wael. 1999. Model Shurūt Works and the Dialectic of Doctrine and Practice. Islamic Law and Society 22/2: 109-34.

Hasan, Farhat. 2006. State and Locality in Mughal India: Power Relations in Western India, c. 1572-1730. Cambridge: Cambridge University Press. 
Islam, Riazul. 1979. A Calendar of Documents on Indo-Persian Relations, 1500-1750, vol. 1. Tehran: Iranian Cultural Foundation.

Khare, G.H. The Archives of the Deshmukh Family of Sholapur (Bombay). Proceedings of the Indian History Congress 16 (1953): 273-5.

King, Christopher. 1994. One Language, Two Scripts: The Hindi Movement in NineteenthCentury North India. New Delhi: Oxford University Press.

Kinra, Rajeev. 2010. Master and Mūnshī: A Brahman Secretary's Guide to Mughal Governance. Indian Economic and Social History Review 47/4: 527-561.

Kinra, Rajeev. 2015. Writing Self, Writing Empire: Chandar Bhan Brahman and the World of the Indo-Persian State Secretary. Oakland: University of California Press.

Kothiyal, Tanuja. 2016. Nomadic Narratives: A History of Mobility and Identity in the Great Indian Desert. New Delhi: Cambridge University Press.

Lhost, Elizabeth. 2017. Between Community and Qānūn: Documenting Islamic Legal Practice in Nineteenth-Century British India, unpublished $\mathrm{PhD}$ thesis. University of Chicago.

Lhost, Elizabeth. 2018. Writing Law at the Edge of Empire: Evidence from the Qazis of Bharuch (1799-1864). Itinerario 42/2: 256-78.

Liu, Lydia. 2004. Clash of Empires: The Invention of China in Modern World Making. Cambridge, Mass.: Harvard University Press.

Mallat, Chibli. 2004. From Islamic to Middle Eastern Law, Part II. The American Journal of Comparative Law 52/1: 209-86.

Martin, Anna. 2017. "Translator's Invisibility": Strategies of Adaptation in Persian Versions of Indian Tales from the Mughal Period. Iran Namag 2/2: xxiv-xxxvii.

Mitchell, Colin. 1997. Safavid Imperial Tarassul and the Persian Inshä'Tradition. Studia Iranica 27: 173-209.

O'Hanlon, Rosalind. 2010. The Social Worth of Scribes: Brahmins, Kāyasthas and the Social Order in Early Modern India. Indian Economic and Social History Review 47/4: $563-95$.

O'Hanlon, Rosalind. 2013. Performance in a World of Paper: Puranic Histories and Social Communication in Early Modern India. Past and Present 219 (2013): 87-126.

O'Hanlon, Rosalind. 2019. In the Presence of Witnesses: Petitioning and Judicial 'Publics' in Western India, circa 16oo-1820. Modern Asian Studies 53/1 (2019): 52-88.

O'Hanlon, Rosalind. 2020. Entrepreneurs in Diplomacy: Maratha Expansion in the Age of the Vakil. Indian Economic and Social History Review 57/4: 5०3-34.

Orsini, Francesca, ed. 2010. Before the Divide: Hindi and Urdu Literary Culture. Hyderabad: Orient Blackswan.

Orsini, Francesca and Schofield, Katherine Butler, ed. 2015. Tellings and Texts: Music, Literature and Performance in North India. Cambridge: Open Book Publishers.

Paul, Jürgen. 1995. Inshä' Collections as a Source of Iranian History. In Proceedings of the Second European Conference of Iranian Studies (Bamberg, 1991), ed. Bert Fragner et al. Rome: IsMEO. 
Poster, Carol and Linda Mitchell, ed. 2007. Letter Writing Manuals and Instruction:From Antiquity to the Present: Historical and Bibliographic Studies. Columbia: University of South Carolina.

Raman, Bhavani. 2012. Document Raj: Writing and Scribes in Early Colonial South India. Chicago: University of Chicago Press.

Ricci, Ronit. 2011. Islam Translated: Literature, Conversion and the Arabic Cosmopolis of South and Southeast Asia. Chicago: University of Chicago Press.

Richards, John F. 1975. The Mughal Administration of Golconda. Oxford: Clarendon Press.

Salomon, Richard. 1998. Indian Epigraphy: A Guide to the Study of Inscriptions in Sanskrit, Persian and Other Indo-Aryan Languages. Oxford: Oxford University Press.

Sarcevic, Susan. 1997. New Approach to Legal Translation. The Hague: Kluwer Law International.

Sardesai, G.S. 1933. Handbook to the Records in the Alienation Office, Poona. Bombay: Government Central Press.

Sartori, Paolo and Pickett, James. 2019. From Archetypical Archives to Cultures of Documentation. Journal of the Economic and Social History of the Orient. 62/5-6: 773-98.

Saswadkar, P.L. A Note on the Kotwali of Poona in the Last Quarter of the Eighteenth Century. Proceedings of the Indian History Congress 24 (1961): 274-80.

Sharma, Rambabu. 1980. Rājbhāshā Hindī ki Kahānī. New Delhi: Ankur Prakashan.

Sinh, Raghubir. 1936. Malwa in Transition, First Phase 1698-1765. Bombay: D.B. Taraporevala.

Sontheimer, Günther-Dietz. 1989. Pastoral Deities in Western India, trans. Anne Feldhaus. Oxford: Oxford University Press.

Stark, Ulrike. 2007. An Empire of Books: The Naval Kishore Press and the Diffusion of the Printed Word in Colonial India. Ranikhet: Permanent Black.

Truschke, Audrey. 2016. Culture of Encounters: Sanskrit at the Mughal Court. New York: Columbia University Press.

Vendell, Dominic. 2018. Scribes and the Vocation of Politics in the Maratha Empire, 1708-1818, unpublished PhD thesis. Columbia University.

Vendell, Dominic. 2021. Market Governance and Social Plurality in SeventeenthCentury Western India. Leiden: European Social Sciences History Conference.

Venuti, Lawrence, ed. 2000. The Translation Studies Reader. London: Routledge.

Venuti, Lawrence. 2008. The Translator's Invisibility: A History of Translation, 2nd ed. Abingdon: Routledge.

Wagle, N.K. 200o. The Government, the Jāti and the Individual: Rights, Discipline and Control in the Pune Kotwal Papers, 1766-1794. Contributions to Indian Sociology 34/3: 321-6o.

Werner, Christoph. 2003. Formal Aspects of Qajar Deeds of Sale. In Persian Documents. Social History of Iran and Turan in the Fifteenth-Nineteenth Centuries, ed. Nobuaki Kondo. London: Routledge Curzon: 13-49. 
Wigh, Sonia. 2014. Power, Patronage and Sexuality In Mughal India: A Study Of The Language of Biharilal \& Mir Jafar Zatalli, unpublished M.Phil. thesis. Jawaharlal Nehru University.

Wink, André. 1988. Land and Sovereignty in India: Agrarian Society and Politics under the Eighteenth Century Maratha Svarājya. Cambridge: Cambridge University Press.

Wolff, Leon. 2011. Legal Translation. In The Oxford Handbook of Translation Studies, ed. Kirsten Malmkjaer and Kevin Windle. Oxford: Oxford University Press: 228-42.

Xuan, Ji and Dong Xiaobo. 2017. Equivalence Theory and Legal Translation: Achieving Functional Equivalence in Chinese and English Legal Terminology. Chinese Semiotic Studies 13/2: 123-35. 